\title{
Layers of Self- and Co-Regulation: Teachers Working Collaboratively to Support Adolescents' Self-Regulated Learning through Reading
}

\author{
Deborah L. Butler, ${ }^{1}$ Leyton Schnellert, ${ }^{2}$ and Sylvie C. Cartier ${ }^{3}$ \\ ${ }^{1}$ Faculty of Education, University of British Columbia, Vancouver, 2125 Main Mall, Vancouver, BC, Canada V6T 1Z4 \\ ${ }^{2}$ Faculty of Education, University of British Columbia, Okanagan, EME 3157, 3333 University Way, Kelowna, BC, Canada V1V 1 V7 \\ ${ }^{3}$ Département de Psychopédagogie et d’Andragogie, Faculté des Sciences de l'Éducation, Université de Montréal, C.P. 6128, \\ Succursale Centre-ville, Montréal, QC, Canada H3C $3 J 7$
}

Correspondence should be addressed to Deborah L. Butler; deborah.butler@ubc.ca

Received 22 May 2012; Revised 3 November 2012; Accepted 6 December 2012

Academic Editor: Nancy Perry

Copyright $\odot 2013$ Deborah L. Butler et al. This is an open access article distributed under the Creative Commons Attribution License, which permits unrestricted use, distribution, and reproduction in any medium, provided the original work is properly cited.

\begin{abstract}
This paper reports findings from a longitudinal project in which secondary teachers were working collaboratively to support adolescents' self-regulated learning through reading (LTR) in subject-area classrooms. We build from prior research to "connect the dots" between teachers' engagement in self- and co-regulated inquiry, associated shifts in classroom practice, and student selfregulation. More specifically, we investigated whether and how teachers working within a community of inquiry were mobilizing research to shape classroom practice and advance student learning. Drawing on evidence from 18 teachers and their respective classrooms, we describe findings related to the following research questions: (1) While engaged in self- and co-regulated inquiry, what types of practices did teachers enact to support LTR in their subject-area classrooms? (2) How did teachers draw on researchbased resources to inform practice development? (3) What kinds of practices could be associated with gains in students' selfregulated LTR? In our discussion, we highlight contributions to understanding how teachers can be supported to situate research in authentic classroom environments and about qualities of practices supportive of students' self-regulated LTR. We also identify limitations of this work and important future directions.
\end{abstract}

\section{Introduction}

In this paper, we present findings from the second year of a longitudinal project in which secondary teachers in Western Canada were working collaboratively with researchers to better understand and support adolescents' self-regulated learning through reading (LTR) in subject-area classrooms. In this project, a central goal has been to advance understanding about students' self-regulated LTR as situated in classroom contexts [1]. However, if we are to make a meaningful difference for students, also essential is studying how teachers can be supported to embed practices supportive of students' self-regulation into authentic classroom environments. To that end, in the longitudinal project, we have been studying teachers' engagement in self- and co-regulated inquiry as they work together to develop practices supportive of students' self-regulated LTR [2-4].

Extending from prior work, in this paper we "connect the dots" between teachers' engagement in self- and co-regulated inquiry, associated shifts in classroom practice, and student outcomes. More specifically, we investigated whether and how teachers working within a community of inquiry were mobilizing research to shape classroom practice and advance student learning. Drawing on evidence from 18 teachers and their respective classrooms, we addressed the following research questions: (1) While engaged in self- and coregulated inquiry, what types of practices did teachers enact to support LTR in their subject-area classrooms? (2) How did 
teachers draw on research-based resources to inform practice development? (3) What kinds of practices could be associated with shifts in students' self-regulated LTR?

\section{Self- and Co-Regulated Inquiry in Teachers' Professional Development}

It is increasingly recognized that improving student outcomes in classrooms is dependent on teachers' professional learning (e.g., see [5-8]). As a result, research is being called for that both associates qualities of professional development with teachers' contextualized use of promising literacy practices and traces how practice shifts that emerge through professional learning are associated with gains in adolescents' literacy performance [9-11]. In response to this call, we have been investigating how teachers' professional development supports not only teacher learning and practice revisions, but also more positive outcomes for students.

More specifically, in the research reported here, we studied whether and how teachers working within a "community of inquiry" were mobilizing research to inform practice and achieve positive outcomes for learners. Critics of transmission or prescriptive approaches to professional development have suggested they are particularly ineffective in supporting contextualized and sustained shifts in classrooms [5, 12-14]. As an alternative, newer initiatives are embedding professional development within communities of inquiry wherein individuals work together to co-construct and situate emerging knowledge and beliefs [3, 4, 1521]. Building from these initiatives, in this research, we studied whether and how an inquiry-oriented approach to professional development might support teachers in making research-practice connections.

To inform our study, we applied a socioconstructivist model of self- and co-regulation to characterize teachers' inquiry processes (see [3, 4, 22]). Models of self- and coregulation are most often applied to understanding students' engagement in learning, (e.g., [23-30]). Students are described as self-regulating when they deliberately orchestrate learning so as to achieve goals, by planning and enacting strategies, monitoring progress and outcomes, and adjusting activities as needed. However, in Figure 1, we depict how we have described teachers' working to set goals, plan, enact, and monitor classroom practices as something that they also "self-regulate" $[4,12]$. In a community of inquiry, teachers are typically supported to identify and set goals for practice and student learning, plan practices to achieve goals, situate those practices meaningfully in classroom settings to meet students' needs, monitor challenges and benefits for learners, and adjust approaches as needed. By engaging in these kinds of self-regulating strategies in a sustained way over time, teachers have opportunities to engage in iterative cycles of practice refinement so as to advance students' learning.

As is referenced in Figure 1, our layered model of self- and co-regulation also suggests that when teachers participate in professional development (formal or informal), they can also deliberately advance their own professional learning in/through practice $[2,4,15]$. Indeed, to inform understanding about teachers' professional development, we have found

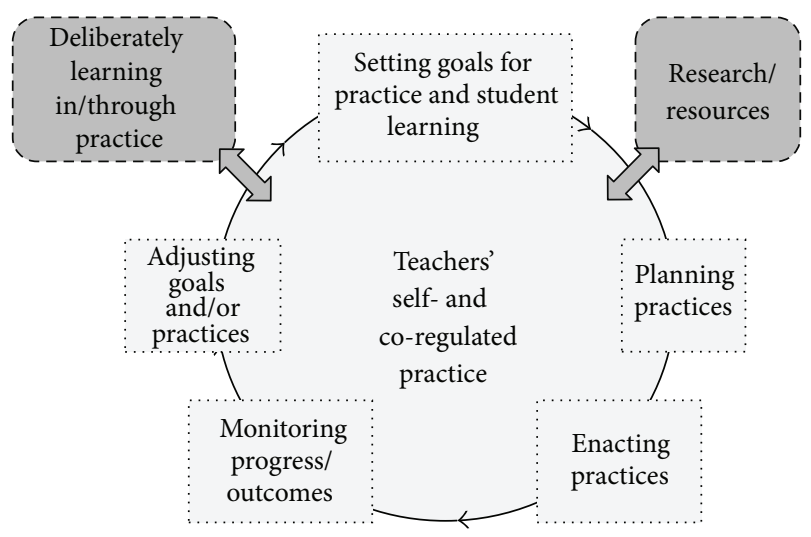

Figure 1: Teachers' engagement in cycles of self- and co-regulated inquiry (see also [4]).

it useful to distinguish teachers' self-regulation of practice (i.e., SRP) from their self-regulation of their own learning (i.e., SRL) [2-4]. When self-regulating practice, teachers strategically orchestrate their work in classrooms so as to advance student learning. When self-regulating their own learning, teachers might extend their professional competence deliberately by setting learning goals (e.g., to learn more about SR and how to support it in their classroom), planning for learning (e.g., to join a study group), self-monitoring (e.g., their progress in learning), and making adjustments as needed (e.g., to access other kinds of resources). To advance professional learning, our past research has suggested that the ideal is for teachers' deliberate engagement in SRL to be intimately connected to their reflective and iterative engagement in cycles of SRP $[2,4,15]$.

We would note that a particular benefit in a community of inquiry is that teachers have opportunities to engage in inquiry processes together $[4,6,15,20,21,31-33]$. In the theoretical model applied here, we therefore extend the concept of "co-regulation" to describe teachers' collaborative inquiry within professional development initiatives. Models of self-regulation do not just focus on "in-the-head" processes of individuals; instead, they characterize the complex interplay between individual and social processes [34-37]. For example, research suggests how teachers can structure activities, instruction, or assessment so as to "co-regulate" students' engagement in activities as a way of developing selfregulation in reading, writing or other forms of academic work (e.g., [38-43]). In past projects, we have built from this theoretical perspective to conceptualize and study teachers' engagement in collaborative inquiry. For example, we have examined the depth and quality of teachers' co-regulated practice and professional learning when teachers work with colleagues (e.g., peers, mentors) to set goals, plan for teaching, enact classroom practices, monitor outcomes, and revise practices accordingly $[4,15,22]$.

In previous reports, we demonstrated the heuristic value of this theoretical framework for conceptualizing teachers' engagement in inquiry [2-4]. We also documented how when teachers engaged in collaborative inquiry, they experienced significant gains in professional learning and classroom 
practice $[2,4,15,44]$. To advance this line of research, in this study, we focused on whether and how teachers were drawing on research-informed resources to shape practices developed in inquiry cycles. Building from our layered model of professional learning as depicted in Figure 1, we hypothesized that research could have an impact on practice to the extent that it informed teachers' iterative engagement in goal-directed cycles of self- and co-regulated inquiry (see also [45]). This perspective motivated this investigation of how the availability of research-based resources within a community of inquiry could be associated with teachers' practice development.

\section{Students' Self-Regulated Learning through Reading}

The community of inquiry studied here formed with the common goal of refining classroom practices so as to advance adolescents' learning through reading (LTR) within subjectarea classrooms. At the secondary level, subject-area teachers rely heavily on students' ability to engage in reading as an important vehicle for learning. The result is that to thrive in today's classrooms, adolescents must navigate complex LTR tasks, often involving multiple types of text (e.g., narrative and expository: textbooks, primary source documents, websites) [46-51].

LTR provides a good example of a kind of academic work that requires effective self-regulation. LTR activities challenge students to recognize the demands in particular settings (e.g., LTR in history or science), coordinate multiple types of knowledge, beliefs, perceptions, and conceptions (e.g., about a topic; LTR tasks; fields of study; themselves as learners) and plan and manage use of multiple reading and learning strategies [52-56]. Expectations in LTR include not just "comprehending," but also engaging actively with information (e.g., drawing inferences, applying ideas), participating in discipline-specific discourses (e.g., in history or science), and adapting reading and learning strategies to match task requirements and teacher expectations $[53,56,57]$. Ample research has documented the importance of students' SR and higher-level thinking if they are to construct meaning and learn from reading $[58,59]$.

In this project, researchers and teachers worked again from a socioconstructivist model of self- and co-regulation to inform their efforts to better understand and support students' engagement in LTR (see [60, 61]; see also [2330]). A version of this model is depicted in Figure 2, which is designed to illustrate how, in this research, teachers' engagement in self-regulated and co-regulated inquiry was centered on enhancing students' self-regulated LTR. Teachers in this study worked from a more elaborated model that added attention to how students bring to bear knowledge (e.g., in a given subject area; about strategies), beliefs (e.g., self-perceptions of competence and control), conceptions (e.g., about learning in science), and emotions (e.g., stress or worry) that mediate their engagement in activities. Figure 2 represents the importance of students' enacting reading and learning strategies well matched to the demands of a particular LTR activity (e.g., to learn from particular texts in

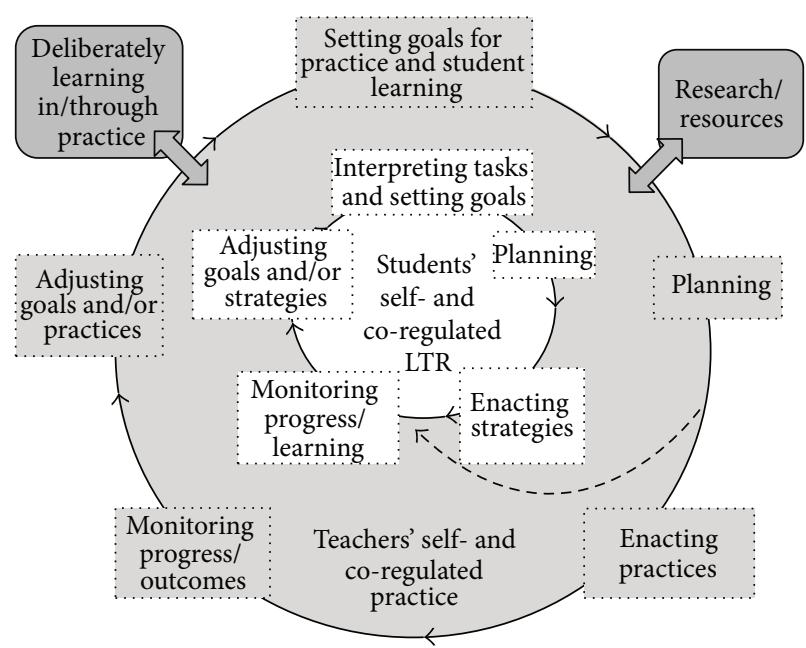

FIGURE 2: Layers of self- and co-regulation (see also [4]).

a given humanities classroom). It also depicts how strategy use is best situated within cycles of self-regulation [38, 57]. As outlined previously, self-regulating learners ideally engage in iterative learning processes that include interpreting tasks and setting goals, planning, selecting, and enacting task-relevant strategies, monitoring progress and learning (e.g., self-assessing), and adjusting goals and/or strategies as needed (to manage motivation and emotions; to improve learning).

Unfortunately, in spite of the centrality of LTR to adolescents' school success, research has documented that secondary-level students often experience significant challenges when self-regulating their performance in LTR activities, (e.g., $[55,62])$. Consistent with that research, formative assessment data collected by teachers as part of this project revealed important strengths and gaps in students' selfregulated LTR (see also [1]). For example, at the start of the academic year, students reported relatively high selfperceptions of competence and control. While teachers have mostly been encouraged by these positive self-perceptions, which can be associated with strategic engagement and persistence through difficulty (see [63]), in some cases, students' self-perceptions were clearly inflated. Teachers were also concerned that students were paying little attention to self-regulating strategies such as planning or self-monitoring. Equally troubling was that, while students reporting using strategies for working with text (e.g. pay attention to bold words) and building meaning (e.g., think about what I know), they were much less likely to report using more active meaning-making strategies (e.g., find links; think of examples; apply ideas; summarize). Consistent with selfreports, performance-based assessments also revealed how students struggled to engage in richer, meaning-making activities such as drawing inferences, analyzing information, and relating main ideas and details when making notes. It was overcoming these kinds of challenges that in large part motivated teachers' decision to focus on supporting selfregulated LTR in their classrooms. 
Fortunately, research has identified classroom practices with potential to support more effective self-regulation (e.g., see $[44,57,64-66])$ and/or LTR (e.g., see [46-49, 55, 56, 59, $67])$. Essential then is to study how teachers can be assisted to draw on research-informed resources to inform their practice development. To that end, in this research, teachers were supported to draw on a rich array of resources, from workshops, research reports, professional articles, mentors, and peers, to consider how they might refine practices to support their students' self-regulated LTR. In this paper, we trace how practices teachers enacted could be related to those resources. We also identify the types of practices that were most closely associated with gains in student outcomes.

\section{Methodology}

Case study designs are particularly useful for advancing understanding about self- and co-regulation as situated in authentic classrooms [68-70]. For example, by creating a frame for collecting and juxtaposing multiple forms of data on both individuals and environments, case study designs support investigating self- and co-regulation as multidimensional, dynamic activities inextricably wedded to context.

In prior reports, we have described our overall research design as "encompassing multiple, context-dependent case studies at the classroom level, each of which preserved meaning in context" (see [1, page 79]). Our approach has involved creating descriptive portraits of secondary students' engagement within particular LTR activities in subject-area classrooms, and then moving "upwards" and "downwards" across levels of aggregation (e.g., individual, class, grade, school) to consider how patterns observed at the classroomlevel relate to patterns at other levels (i.e., whether a gradelevel pattern in a given school was common across classes or masked between-class differences). Through this approach, we have identified both common patterns and important variances in students' LTR across classrooms, consonant with a situated view of SR that locates the meaning of action in context.

Taking this approach has also enabled us to associate practices enacted within and across classrooms with learning outcomes for students working in particular contexts. In other words, our case study methodology has enabled us to "connect the dots" between teachers' activity and student learning in naturalistic settings. In the research reported here, we extended our case study methodology to investigate how teachers drew on research-informed resources within cycles of self- and co-regulation (see also [2-4]). We report findings in which we examined links between resources, qualities of practices, and outcomes for students.

4.1. Research Context. This project overall involved 18 teachers from three secondary schools located within an urban, multicultural school district within Western Canada who had been working over time in a community of inquiry to better understand and promote students' self-regulation in LTR activities (see [1] for detailed information on the inquiry community). An important contextual influence was that the Ministry of Education in the province had instituted an accountability cycle requiring school districts to develop goals, implementation plans, and assessment strategies (see [71]). For their adolescent literacy project, the participating district supported the collaborative development of assessment tools that could be used, not just for reporting on outcomes (for their accountability contract), but also for guiding and monitoring practice within and across classrooms and schools. A role of the research team in the inquiry community has been to support teachers in their construction and interpretation of assessments in ways that they might find meaningful for supporting students' selfregulated engagement in LTR.

The district participating in this research had established a culture of ongoing inquiry as a means of fostering teachers' ongoing practice improvements. Interpreted in relation to our theoretical framework, we considered this as an example of an overall environment where social practices favored and encouraged teachers' engagement in cycles of self- and coregulated practice and learning.

We considered too that the resources made available in the project would provide language and tools that would inform but also delimit how teachers engaged in collaborative inquiry. Notable here was that teachers had access to two kinds of resources: (1) theoretical frameworks that articulated important instructional goals (i.e., about self-regulation in LTR; provincial curricula), along with associated guidelines for constructing assessments, and (2) ideas and support from resources (research articles or professional resources; literacy leaders; colleagues). Thus, what we looked for in our analyses was whether and how these resources informed teachers' efforts to improve student learning (see also [15]).

A relatively complete overview of resources available to teachers is provided in Figure 3. District-level resources are explained in more detail in Table 1. These figures show how professional development activities took place at both the district and school levels. In addition to support provided to teachers' collecting, interpreting, and setting goals based on formative assessment data, professional development activities also assisted teachers to identify practices supportive of LTR (e.g., literacy practices described in research or in use by peers) and to collaborate productively (e.g., planning collaboratively on how to achieve goals). At the school level, literacy leaders supported teachers through co-planning, coteaching, and/or hosting team meetings where idea sharing and/or collaborative partnerships could emerge. In this work, part of literacy leaders' role was to help mediate their colleagues' engagement with ideas drawn from research. Thus, in important respects, the structure of the district's professional development initiative was designed to cue and scaffold teachers' interweaving of cycles of self- and coregulated inquiry and, in that context, to support their drawing on a range of research-based resources to inform practice development.

4.2. Data Collection. Figure 4 overviews the multiple forms of data collected as part of our overall case study design. Taken together, these displays show collection strategies have afforded examining students' thinking about and performance in LTR activities in relation to teachers' engagement 
TABLE 1: Professional development activities available to participants at the district level.

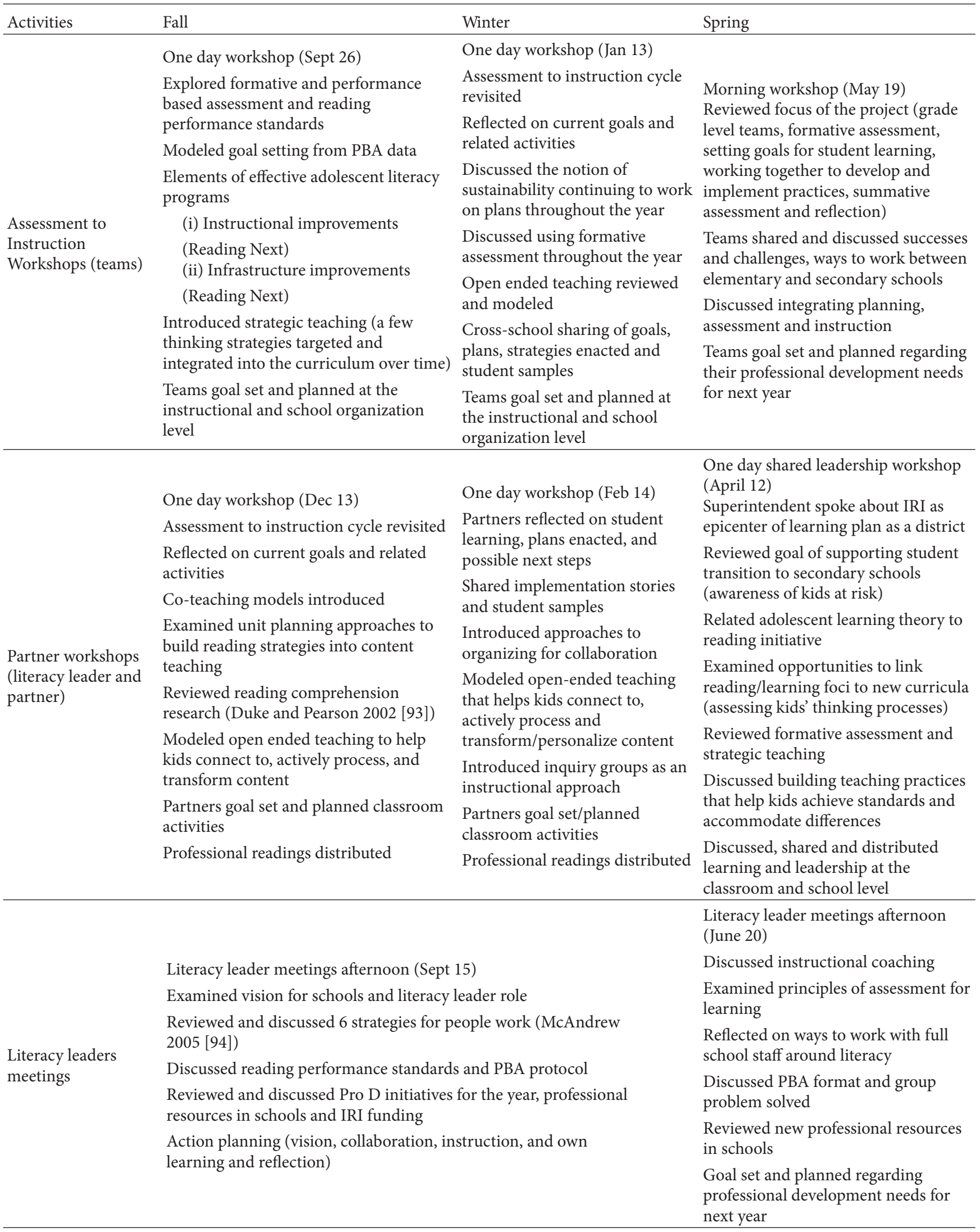


TABLE 1: Continued.

\begin{tabular}{|c|c|c|c|}
\hline Activities & Fall & Winter & Spring \\
\hline \multirow{12}{*}{$\begin{array}{l}\text { Second shot program } \\
\text { development (second } \\
\text { shot teachers and } \\
\text { literacy leaders) }\end{array}$} & Morning meeting/workshop (Sept 15) & After school 3 hour meeting (Feb & Morning meeting (June 28) \\
\hline & Reviewed development process to date & & Reviewed Deschler's content literacy \\
\hline & Shared progress to date & Reviewed structure of IRI & curriculum \\
\hline & & initiative & Reviewed Allington's research on \\
\hline & within schools & Reviewed second shot course & struggling readers \\
\hline & Shared assessment practices and goals set & goals & Reviewed second shot course goals \\
\hline & for students & Reviewed reading & \\
\hline & Shared instructional plans to date & comprehension research & Reviewed instructional approaches \\
\hline & Reviewed unit planning, lesson planning, & $\begin{array}{l}\text { Brainstormed and discussed } \\
\text { challenges and questions }\end{array}$ & $\begin{array}{l}\text { (gradual release, strategic teaching, } \\
\text { four blocks, open ended teaching) }\end{array}$ \\
\hline & $\begin{array}{l}\text { comprehension and metacognition } \\
\text { strategies and instructional approaches }\end{array}$ & $\begin{array}{l}\text { Shared implementation stories, } \\
\text { student samples and units and }\end{array}$ & Examined engaging and accessible \\
\hline & Reviewed unit/lesson planning, & lessons & \\
\hline & $\begin{array}{l}\text { strategies, and instructional approaches } \\
\text { Goal set and planned classroom activities }\end{array}$ & $\begin{array}{l}\text { Goal set and planned classroom } \\
\text { activities }\end{array}$ & $\begin{array}{l}\text { Goal set and planned regarding groups } \\
\text { professional development needs for } \\
\text { next year }\end{array}$ \\
\hline
\end{tabular}

in professional learning and practice development. As is depicted in this figure, participating teachers gathered data for all of their students at the start (Fall) and end (Spring) of the academic year, to aid them in understanding student needs, planning for instruction, and monitoring outcomes. Note here that we only accessed data for research purposes with consent/assent from parents and students, respectively. We analyzed data collected on teachers' learning and practice development for 18 teachers across a full year. To evaluate connections between practice changes and student outcomes, we drew on data from 20 humanities classes taught by 12 teachers, including 364 students.

To afford understanding of students' self-regulated engagement in academic work, in prior research, we have developed and validated an array of data collection strategies (e.g., interviews; questionnaires; think-alouds; think-pairshare activities; learning logs; structured classroom observations; performance traces; achievement measures) (e.g., $[38,43,68,72-76])$. For this project, teachers drew on two of those tools: the Learning through Reading Questionnaire (LTRQ) and the Performance-Based Assessment (PBA).

First, teachers employed the LTRQ to tap into how students were thinking and feeling about their engagement in self-regulation within LTR activities as situated in classrooms (see Figure 5). A unique quality of the LTRQ $[60,61]$ is that it is situated within a given learning activity and context (i.e., "read this text to learn about this topic within this subject area"). To date, versions of this tool have been created to study students' engagement in Learning through Reading (the LTRQ; see [1, 60, 61]), Inquiry Learning in Science (the ILQ; see [77]), and Engineering Design (the EDQ; see [75]). It is critical to stress that the contribution of this tool (in all variants) is to assess, not actual behavior, but how students think and feel about academic work and their engagement within it, as situated within particular contexts [60, 61]. For this research, we drew on LTRQ data to consider how students' perceptions about themselves as learners and their participation in LTR activities could be related to practices enacted by teachers in their particular classrooms.

Second, to create a more complete portrait of students' self-regulation that juxtaposed their thinking about LTR tasks (i.e., on the LTRQ) with a measure of actual performance, we also worked with teachers to construct and interpret situated PBAs following guidelines provided by Brownlie et al. [78]. The PBA assesses how students build meaning from text during a given LTR activity within a given subject area (see Figure 5). In this research, we linked administration of the LTRQ to the PBA to allow relating data between the two measures. Specifically, students completed the LTRQ while referring to the texts and tasks they would complete as part of the PBA, then they completed the PBA shortly thereafter. In this year of the project, teachers coordinated PBA development within and across subject areas and grade levels (i.e., students in the same grade and subject completed the same PBA; PBA versions were parallel in format/style across contexts). Each PBA variant required students to read one or more texts and then respond to open-ended questions. Teachers also conferenced with students as they were working to ask questions about strategy use and meaning making. Teacher teams scored PBAs collaboratively, with researchers' assistance, in relation to provincial performance standards for reading informational text.

Across the year, we also traced the professional learning and practice development of teachers. For this paper, data collection methods included Fall and Spring interviews, observations, and documents/artifacts gathered to assess (1) how teachers drew on resources to inform their practice development and (2) the quality of practices teachers engaged to promote literacy by their students. Again, to describe literacy practices as associated with teachers' use of resources, we reviewed data for 18 teachers across three schools sites, three of whom were literacy leaders (one per site) (see Table 2 for data available for each of these teachers). To link practice changes with student outcomes, we related pre-post 


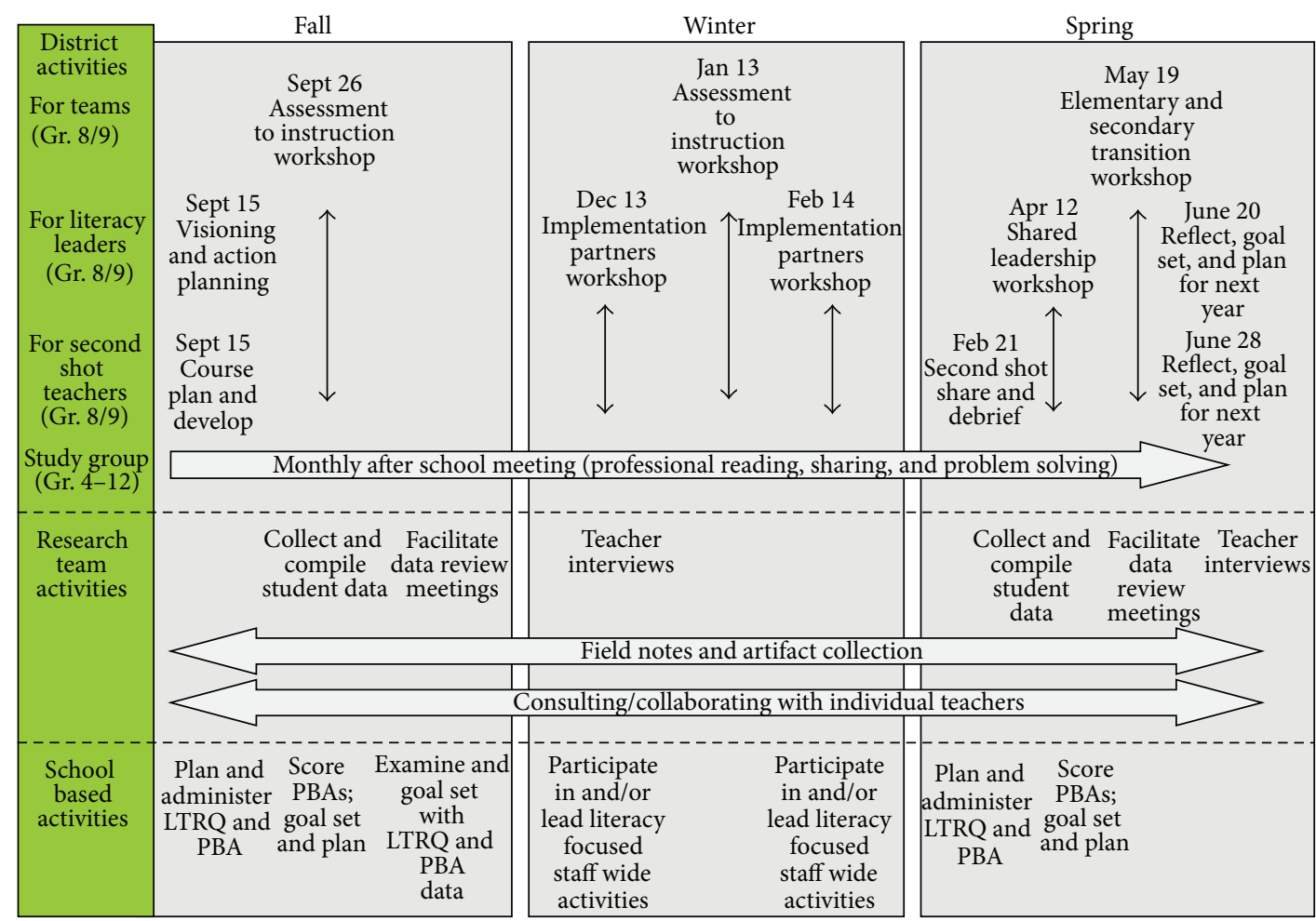

Figure 3: Professional development activities available to project participants at the district and school levels.

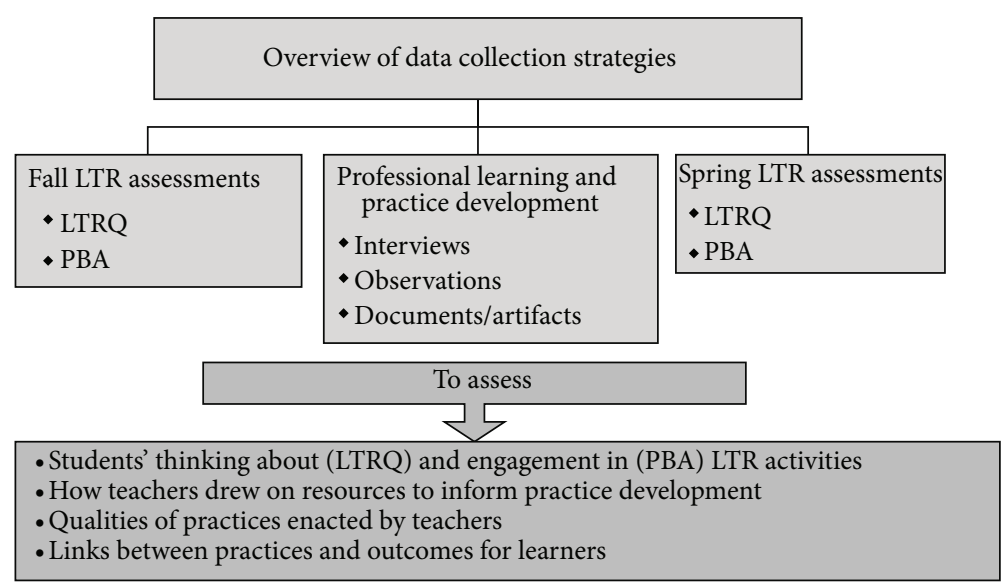

FIgURE 4: Overview of data collection strategies.

shifts in students' self-regulated LTR for 364 students in relation to practices enacted by 12 teachers in 20 humanities classrooms.

\subsection{Data Analyses}

4.3.1. Students' Engagement in LTR. We scored and summarized LTRQ and PBA data following processes described more completely elsewhere $[1,3,79]$. In brief, to support teachers' instructional decision-making, we used frequency analyses to create classroom-level LTR portraits. For the PBA, frequency distributions represented the number of students within and across classrooms who were achieving at different levels, overall (in "snapshot" scores) and for each of the PBA dimensions. For the LTRQ, we visually displayed the distribution of students' responses within and across classrooms for each of the main constructs associated with our model of self-regulation (e.g., students' perceptions of competence and control; task interpretation; reported strategy use). We also used factor analyses to define stable and reliable dimensions underlying LTRQ responses (summarized in Figure 5). We used repeated-measures, multivariate analyses of variance to assess Fall to Spring changes. 
TABLE 2: Data sources available for each teacher.

\begin{tabular}{|c|c|c|c|c|c|c|c|c|c|c|}
\hline Teacher & $\begin{array}{c}\text { LTRQ Fall } \\
\text { data }\end{array}$ & $\begin{array}{c}\text { PBA Fall } \\
\text { data }\end{array}$ & $\begin{array}{l}\text { Interview } \\
\text { fall }\end{array}$ & $\begin{array}{c}\text { Field notes } \\
\text { Fall PBA } \\
\text { scoring } \\
\text { meeting }\end{array}$ & $\begin{array}{c}\text { Field notes } \\
\text { Fall LTRQ } \\
\text { debriefing } \\
\text { meeting }\end{array}$ & $\begin{array}{c}\text { Classroom } \\
\text { artifacts }\end{array}$ & E-mail & $\begin{array}{c}\text { LTRQ } \\
\text { Spring data }\end{array}$ & $\begin{array}{c}\text { PBA Spring } \\
\text { data }\end{array}$ & $\begin{array}{l}\text { Interview } \\
\text { Spring }\end{array}$ \\
\hline $\mathrm{AA}$ & $\checkmark$ & $\checkmark$ & $\checkmark$ & $\checkmark$ & $\checkmark$ & & & $\checkmark$ & $\checkmark$ & $\checkmark$ \\
\hline MB & $\checkmark$ & $\checkmark$ & $\checkmark$ & $\checkmark$ & $\checkmark$ & $\checkmark$ & $\checkmark$ & $\checkmark$ & $\checkmark$ & $\checkmark$ \\
\hline DC & $\checkmark$ & $\checkmark$ & & $\checkmark$ & $\checkmark$ & $\checkmark$ & $\checkmark$ & $\checkmark$ & $\checkmark$ & $\checkmark$ \\
\hline SC & $\checkmark$ & $\checkmark$ & & $\checkmark$ & $\checkmark$ & $\checkmark$ & $\checkmark$ & $\checkmark$ & $\checkmark$ & $\checkmark$ \\
\hline $\mathrm{MD}$ & $\checkmark$ & $\checkmark$ & & $\checkmark$ & $\checkmark$ & $\checkmark$ & $\checkmark$ & $\checkmark$ & $\checkmark$ & $\checkmark$ \\
\hline EG & $\checkmark$ & $\checkmark$ & & $\checkmark$ & $\checkmark$ & $\checkmark$ & $\checkmark$ & $\checkmark$ & $\checkmark$ & $\checkmark$ \\
\hline $\mathrm{DM}$ & $\checkmark$ & $\checkmark$ & $\checkmark$ & $\checkmark$ & $\checkmark$ & $\checkmark$ & $\checkmark$ & $\checkmark$ & $\checkmark$ & $\checkmark$ \\
\hline $\mathrm{CM}$ & $\checkmark$ & $\checkmark$ & $\checkmark$ & $\checkmark$ & $\checkmark$ & $\checkmark$ & $\checkmark$ & $\checkmark$ & $\checkmark$ & $\checkmark$ \\
\hline WP & $\checkmark$ & $\checkmark$ & $\checkmark$ & $\checkmark$ & $\checkmark$ & $\checkmark$ & & & & $\checkmark$ \\
\hline $\mathrm{RR}$ & & $\checkmark$ & & $\checkmark$ & $\checkmark$ & $\checkmark$ & & & $\checkmark$ & $\checkmark$ \\
\hline BT & & $\checkmark$ & & $\checkmark$ & $\checkmark$ & $\checkmark$ & & & $\checkmark$ & $\checkmark$ \\
\hline ST & $\checkmark$ & $\checkmark$ & $\checkmark$ & $\checkmark$ & $\checkmark$ & $\checkmark$ & & $\checkmark$ & $\checkmark$ & $\checkmark$ \\
\hline MV & $\checkmark$ & $\checkmark$ & & $\checkmark$ & $\checkmark$ & $\checkmark$ & & $\checkmark$ & $\checkmark$ & $\checkmark$ \\
\hline LW & $\checkmark$ & $\checkmark$ & $\checkmark$ & $\checkmark$ & $\checkmark$ & $\checkmark$ & $\checkmark$ & $\checkmark$ & $\checkmark$ & $\checkmark$ \\
\hline NW & $\checkmark$ & $\checkmark$ & $\checkmark$ & $\checkmark$ & $\checkmark$ & $\checkmark$ & $\checkmark$ & $\checkmark$ & $\checkmark$ & $\checkmark$ \\
\hline GF & $(\checkmark)$ & $(\checkmark)$ & & $\checkmark$ & & $\checkmark$ & & $(\checkmark)$ & $(\sqrt{ })$ & $\checkmark$ \\
\hline DS & $(\sqrt{ })$ & $(\checkmark)$ & & $\checkmark$ & $\checkmark$ & $\checkmark$ & $\checkmark$ & $(\sqrt{ })$ & $(\sqrt{ })$ & $\checkmark$ \\
\hline AG & N/A & N/A & $\checkmark$ & N/A & $\checkmark$ & $\checkmark$ & $\checkmark$ & N/A & N/A & $\checkmark$ \\
\hline
\end{tabular}

Notes: Initials for teachers refer to pseudonyms; LTRQ: Learning through Reading Questionnaire; PBA: Performance-Based Assessment.

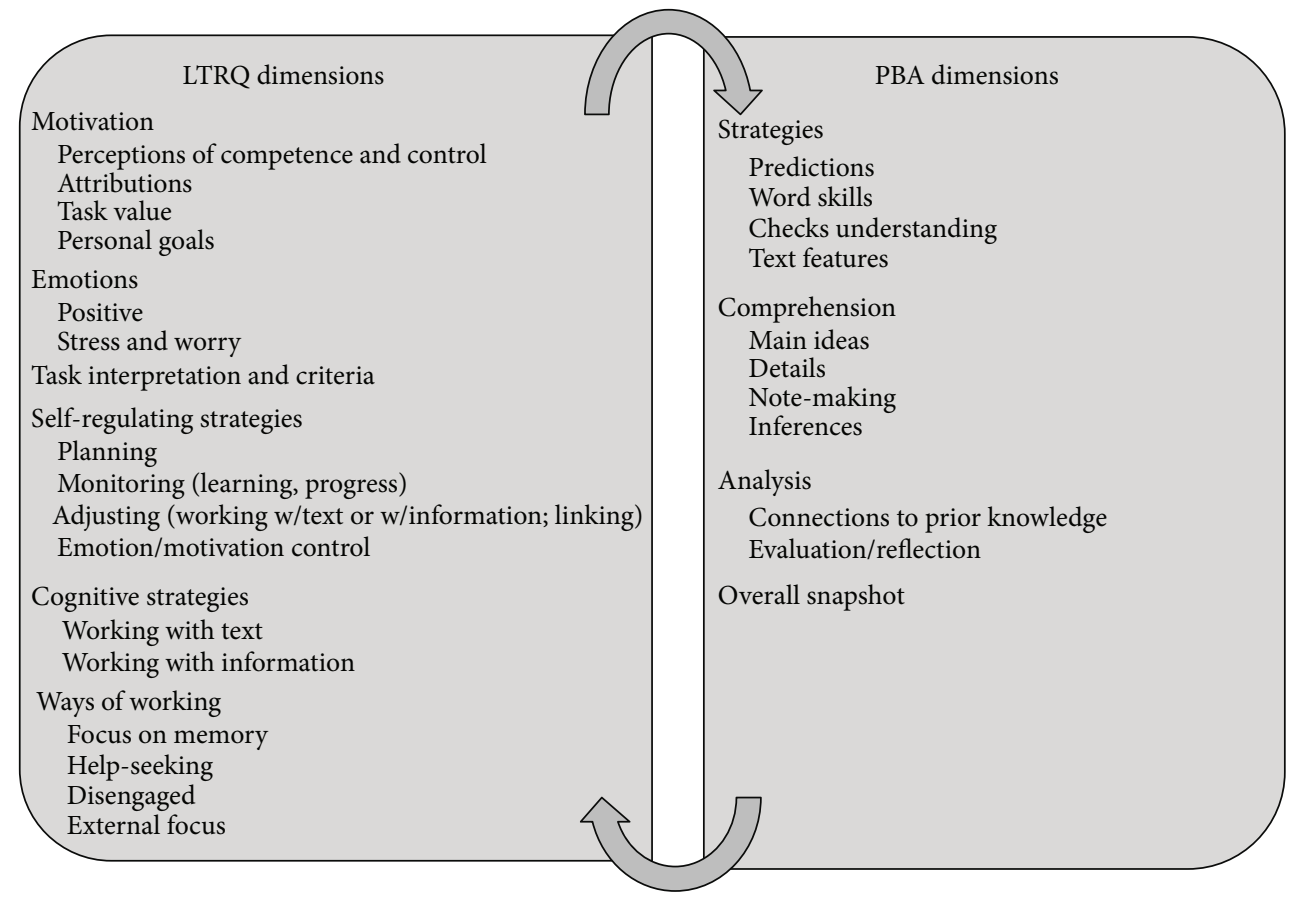

FIGURE 5: Dimensions captured in the Learning through Reading Questionnaire (LTRQ) and the Performance-Based Assessment (PBA). 
TABLE 3: Goals teachers set for improving students' LTR engagement based on situated assessment data.

\begin{tabular}{llcccccc}
\hline Teacher Main ideas & Details & Note-making & Making connections & Making inferences & Visualizing & Text features & Reasoned judgements \\
\hline AG & $\checkmark$ & & $\checkmark$ & $\checkmark$ & $\checkmark$ & $\checkmark$ & $\checkmark$ \\
AA & $\checkmark$ & & $\checkmark$ & $\checkmark$ & $\checkmark$ & $\checkmark$ & $\checkmark$ \\
BT & $\checkmark$ & $\checkmark$ & $\checkmark$ & $\checkmark$ & $\checkmark$ & $\checkmark$ \\
DC & $\checkmark$ & $\checkmark$ & $\checkmark$ & $\checkmark$ & $\checkmark$ & $\checkmark$ & $\checkmark$ \\
DM & $\checkmark$ & $\checkmark$ & $\checkmark$ & $\checkmark$ & $\checkmark$ \\
DS & $\checkmark$ & $\checkmark$ & $\checkmark$ & $\checkmark$ & $\checkmark$ & $\checkmark$ \\
EG & $\checkmark$ & $\checkmark$ & $\checkmark$ & $\checkmark$ & $\checkmark$ & $\checkmark$ \\
GF & $\checkmark$ & & $\checkmark$ & $\checkmark$ & $\checkmark$ \\
LW & $\checkmark$ & $\checkmark$ & $\checkmark$ & $\checkmark$ & $\checkmark$ \\
MB & $\checkmark$ & $\checkmark$ & $\checkmark$ & $\checkmark$ & $\checkmark$ & $\checkmark$ \\
MD & $\checkmark$ & $\checkmark$ & $\checkmark$ & $\checkmark$ & $\checkmark$ & $\checkmark$ \\
MV & $\checkmark$ & $\checkmark$ & $\checkmark$ & $\checkmark$ & $\checkmark$ & $\checkmark$ \\
NW & $\checkmark$ & $\checkmark$ & $\checkmark$ & $\checkmark$ & $\checkmark$ & $\checkmark$ \\
RR & $\checkmark$ & $\checkmark$ & $\checkmark$ & $\checkmark$ & $\checkmark$ & $\checkmark$ \\
SC & $\checkmark$ & $\checkmark$ & $\checkmark$ & $\checkmark$ & $\checkmark$ & $\checkmark$ \\
WP & $\checkmark$ & $\checkmark$ & & $\checkmark$ & $\checkmark$ & $\checkmark$ \\
\hline
\end{tabular}

Notes: Initials for teachers refer to pseudonyms; columns refer to main goals set by teachers.

4.3.2. Teachers' Engagement in Self- and Co-Regulated Practice. To trace teachers' professional learning and practice development, we used a combination of qualitative analysis techniques to interpret and coordinate multiple forms of data. We analyzed interview transcripts in an iterative process to construct, test, revise, and coordinate codes (for details, see $[3,4,69,80,81])$. We mined documents and field notes for confirming or disconfirming evidence. Following recommendations from Miles and Huberman [81], we created data displays (e.g., tables; visual representations) to reveal patterns for interpretation. For example, for analyses of practices reported here, we started by creating low-inference "level one" displays that collected evidence related to goals teachers set and practices enacted. Next, building recursively between an inductive derivation of themes from data and consideration of relevant theory, we developed codes to describe goals and practice qualities that might be associated with students' development of SR. Finally, in "level two" displays, we co-related coded data to surface patterns and warrant conclusions (as in Tables 3 and 5).

4.3.3. Relating Teachers' Practices to Outcomes for Students. We used a variety of analytic tools (see later) to crossreference analyses of instructional practices with LTR gains for students. Consistent with our situated approach to studying self- and co-regulation, we anticipated gains for students as a function of (a) goals teachers worked on and (b) qualities of instruction as implemented in classrooms.

\section{Results}

5.1. Research Question 1. While Engaged in Self- and CoRegulated Inquiry, What Types of Practices Did Teachers Enact to Support LTR in Their Subject-Area Classrooms? To address our first research question, we analyzed data from interviews, observations (e.g., of team planning meetings), and related documents/artifacts (e.g., e-mails, lesson plans) to identify the goals teachers set for students and the practices they enacted to achieve those goals.

5.1.1. Goals Teachers Set. First, case study analyses allowed us to identify goals teachers set for students in their classrooms. Apparent in Table 3 is that teachers targeted goals focused on finding main ideas (all 18 teachers), finding details or supporting note-making (14 teachers each), inferencing (11 teachers), making connections (10 teachers), visualizing (7 teachers), making reasoned judgments (6 teachers), and using text features (5 teachers).

5.1.2. Qualities of Practice Changes. To trace the qualities of practices enacted by teachers, we systematically coded case study data (interviews, field notes from meetings, and artifacts). Following Agar [82], our coding proceeded abductively, cycling between deductive and inductive reasoning. We first categorized practice changes descriptively by kind (e.g., "gradual release"). Then, at a next level of abstraction, we found that practices could be described as reflecting more or less of the following four qualities: sustained attention to goals; integrating LTR goals into the curriculum; explicit attention to reading, thinking, and/or learning processes; promoting/fostering student independence. Definitions and coding criteria for these qualities can be found in Table 4.

5.2. Research Question 2. How Did Teachers Draw on Research-Based Resources to Inform Practice Development? Our case study analyses suggested how both the goals teachers set 
TABLE 4: Coding criteria for instructional qualities evident in teaching practices as represented in interviews and artifacts.

Quality of teachers' instruction

\begin{tabular}{|c|c|c|c|c|}
\hline \multirow{2}{*}{ Dimension } & 1 & 2 & 3 & 4 \\
\hline & Little or no focus & Some focus & Multiple attempts/efforts & Thorough, focused effort \\
\hline $\begin{array}{l}\text { Sustained attention to } \\
\text { goals }\end{array}$ & $\begin{array}{l}\text { Teacher gave little } \\
\text { attention to goals, may be } \\
\text { one shot }\end{array}$ & $\begin{array}{l}\text { Teacher worked on goal in } \\
\text { more than one instance, } \\
\text { but seems to be little sense } \\
\text { of maintaining or building } \\
\text { efforts over time }\end{array}$ & $\begin{array}{l}\text { Teacher made multiple } \\
\text { attempts to work on } \\
\text { goal(s) with a sense of } \\
\text { building over time }\end{array}$ & $\begin{array}{l}\text { Evidence of teacher's very } \\
\text { focused and sequential } \\
\text { work on goal(s) over an } \\
\text { extended period of time }\end{array}$ \\
\hline $\begin{array}{l}\text { Integrating goals into } \\
\text { curricula }\end{array}$ & $\begin{array}{c}\text { Teacher focused on } \\
\text { learning } \\
\text { skill(s)/process(es) but not } \\
\text { how curriculum is linked } \\
\text { to learning processes }\end{array}$ & $\begin{array}{l}\text { Teacher says they focused } \\
\text { on learning } \\
\text { skill(s)/process(es) as } \\
\text { linked to curriculum, but } \\
\text { there is minimal evidence }\end{array}$ & $\begin{array}{l}\text { Teacher describes/shows } \\
\text { how goal(s) was integrated } \\
\text { into curriculum with } \\
\text { explicit attention to how } \\
\text { content and learning } \\
\text { processes are interwoven }\end{array}$ & $\begin{array}{l}\text { Teacher describes/shows } \\
\text { how goal(s) was deeply } \\
\text { and/or consistently } \\
\text { integrated into curriculum } \\
\text { as part of learning in } \\
\text { content area(s) and may } \\
\text { describe how this was } \\
\text { uniquely addressed in } \\
\text { different content areas } \\
\text { and/or texts }\end{array}$ \\
\hline
\end{tabular}

Teacher talked about

Teacher talked about seeking to work on

Explicit attention to reading, thinking, and/or learning processes learning process goal(s) but does not make learning process goals or strategies apparent to students understand and use rather than making attempts to help students learning process goal(s), but does so in a way that just has students do things (e.g., answer a question), learning processes transparent to students

Talked about methods that might support student independence (e.g.,

Promoting/fostering student independence
No mention and/or little evidence of efforts to build student independence practicing a skill learned), but not with student
Teacher talked about how they made efforts to address learning process(es) goals, with specific attention to defining/explicating learning processes (e.g., what a process looks like)
Teacher talked very specifically about ways in which he/she used specific methods to make the what and how of learning process goal(s) explicit and apparent to students

\footnotetext{
Talked about using specific methods designed to foster student independence but without moving to level of promoting active

self-directed learning (e.g., student mastery of specific processes/strategies but not necessarily choosing strategies, selfmonitoring, adapting, etc.)
} independence or SRL explicitly as a goal

Talked about fostering independence in a way that also fosters student self-direction and managing of learning and the practices enacted were shaped by resources available to inform their engagement in cycles of self- and co-regulated inquiry.

5.2.1. Goals Teachers Set. Teachers in this project were free to set goals associated with their students' unique needs. That they did so is apparent in the diversity of goals targeted by teachers (see Table 3 ). That said, many teachers also set common goals for their students. We suggest that this commonality was a function of the teachers having drawn on shared frameworks, jurisdictional performance standards, and assessment tools to assess where students were experiencing challenges and define priorities. As described earlier, Fall data on students' self-regulated LTR revealed that many students were neither prioritizing nor enacting the kinds of active reading and learning strategies essential to successful LTR and articulated as goals in provincial curricula. Thus, it was not surprising that so many teachers identified goals for students in areas such as note-making, inferencing, and making connections.

It is significant that in this project all teachers set goals focused on supporting LTR processes, even though these were subject-area teachers. Prior research has shown that, at the secondary level, instructors often assume students already know how to construct new knowledge through reading in a variety of subject areas [83-87], so that attention in subject-area classrooms does not often focus on supporting adolescents' LTR processes. Thus, it was encouraging that teachers here targeted learning processes as an instructional focus. Consistent with this observation, in final interviews, many teachers explained that they had shifted in how they were balancing attention to teaching content and supporting learning processes within their instruction (see also $[3,4]$ ). Thus, data from the LTRQ and PBA and associated theoretical 
TABLE 5: Implementation quality (1-4) for each teacher for each targeted goal.

\begin{tabular}{|c|c|c|c|c|c|c|c|c|}
\hline Teacher & Main ideas & Details & Note-making & Making connections & Making inferences & Visualizing & Text features & Reasoned judgments \\
\hline AG & 1 & 1 & 2 & 1 & 2 & 1 & 1 & 1 \\
\hline AA & 1 & 1 & 1 & 1 & 1 & 1 & 1 & 1 \\
\hline BT & 1 & 2 & 2 & 2 & 2 & 1 & 1 & 1 \\
\hline $\mathrm{CM}$ & 4 & 1 & 4 & 3 & 2 & 2 & 2 & 1 \\
\hline DC & 2 & 2 & 2 & 1 & 2 & 1 & 1 & 2 \\
\hline $\mathrm{DM}$ & 2 & 2 & 1 & 3 & 2 & 2 & 1 & 2 \\
\hline DS & 3 & 2 & 2 & 3 & 2 & 2 & 1 & 1 \\
\hline EG & 2 & 3 & 3 & 1 & 1 & 2 & 1 & 1 \\
\hline $\mathrm{CF}$ & 1 & 1 & 2 & 1 & 1 & 1 & 1 & 1 \\
\hline LW & 4 & 2 & 4 & 4 & 4 & 2 & 1 & 2 \\
\hline MB & 3 & 2 & 4 & 1 & 2 & 1 & 1 & 1 \\
\hline MD & 2 & 2 & 3 & 3 & 1 & 2 & 1 & 1 \\
\hline MV & 3 & 2 & 2 & 1 & 2 & 1 & 1 & 1 \\
\hline NW & 3 & 3 & 1 & 4 & 1 & 1 & 2 & 1 \\
\hline $\mathrm{RR}$ & 2 & 2 & 2 & 2 & 2 & 1 & 2 & 2 \\
\hline ST & 3 & 3 & 4 & 1 & 2 & 1 & 1 & 1 \\
\hline SC & 2 & 2 & 2 & 2 & 1 & 1 & 2 & 1 \\
\hline WP & 3 & 2 & 1 & 2 & 1 & 2 & 2 & 2 \\
\hline
\end{tabular}

frameworks appeared to direct teachers' attention to important instructional goals that they might not have explicitly targeted.

5.2.2. Qualities of Practice Changes. Case study data also suggested how participating in the district's literacy project shaped the practices teachers enacted. Earlier, we described how theoretical frameworks and assessment tools influenced the goals teachers set in their classrooms. Similarly, the practices teachers enacted were very consonant with researchbased recommendations apparent in resources available at the district and school levels (e.g., in workshops; through mentoring). While the specific form of practices varied across classrooms based on topics addressed and other contextual factors, clear family resemblances were still apparent across practices implemented to achieve teachers' priority goals. For example, many teachers described how the practices they tried enabled them to "gradually release" responsibility for learning to students. These themes, apparent in available resources and echoed across teachers' descriptions of practices, were correspondingly prominent in our qualitative coding of practice qualities (i.e., as sustained, integrated into curricula, explicit, or focused on supporting independence).

While definite themes were apparent across teachers' descriptions of practices, how teachers took up practices in pursuit of goals varied considerably across classes. Reports from teachers suggested that rather than trying to tackle too many goals at one time, they generally decided to focus on the highest priorities for their students first, based on Fall data, and then build to tackle a wider range of issues over time. Consistent with teachers' descriptions, Table 5 reveals the diversity in goals and practices for the 18 teachers for whom we tracked practice changes. In this table, we cross-reference an overall implementation score (across all four practice qualities) with teachers' attention to different LTR goals (e.g., CM's practices reflected the highest level of intensity across all four practice qualities when working on main ideas and notemaking). Apparent in this display is that teachers invested different kinds and amounts of effort to achieve different kinds of goals.

Thus, to conduct a fair evaluation of how practice changes were associated with student outcomes, we needed to associate the goals and practices actually taken up by teachers in classrooms with gains for students in those particular areas. While "messy," adopting this approach allowed us to track the complexity of how practice change was unfolding (iteratively; dynamically) to address students' needs in particular settings.

5.3. Research Question 3. What Practices Could Be Associated with Gains in Students' Self-Regulated LTR? Table 5 describes how teachers' classroom practices reflected four important qualities with promise to support students' self-regulation in LTR activities. In this section, we link these practice qualities to observed outcomes for students. To begin, we describe Fall to Spring changes on the PBA for students in 20 humanities classrooms. Then, we consider how variations in outcomes, both on the LTRQ and the PBA, could be linked to the goals and practice qualities within different classrooms.

5.3.1. Pre-Post Gains in LTR Performance. Analyses of prepost gains for the 364 students working in 20 humanities classrooms revealed statistically reliable gains on the PBA, when data were aggregated across classes. Table 6 presents mean scores and standard deviations overall for the entire sample. For example, pre-post PBA "snapshot" scores for 360 students showed a gain from an average of $2.76(\mathrm{SD}=1.16)$ to $3.90(\mathrm{SD}=1.31)$ between the beginning and end of the year. 
Findings showed that the greatest mean shifts on the PBA across classrooms were on these overall performance scores and on four more specific dimensions: text features, main idea, inferences, and connections, corresponding with the goals most heavily emphasized by teachers. Note here that the difference in N's across dimensions resulted both from missing data (e.g., from absenteeism) and from slightly different PBA forms being used across grade levels. Specifically, as is represented using " $\mathrm{n} / \mathrm{a}$ " in the table, predicting, checks understanding, and accuracy/completeness were not assessed at the Grade 9 level.

The findings from multivariate analyses summarized in Table 6 reveal that the main effect of "time" was statistically reliable across all measured dimensions (suggesting FallSpring gains). But our analyses also revealed statistically reliable interactions between time and classrooms (see Table 6). We concluded that, while on average students increased in LTR performance, changes in performance were mediated by the classrooms in which students were working.

\subsubsection{Relating Qualities of Instruction to Pre-Post Gains for} Students on the LTRQ. Further analyses revealed significant correlations between the qualities of teachers' practices and gains on LTRQ dimensions associated with the goals on which teachers were working (see Table 7). Building from this, we suggest that our methodological logic established internal validity (i.e., relating practice changes to outcomes) by anticipating changes only in relation to the qualities of practice changes teachers made to target particular goals, in comparison to areas where they had not yet focused attention. Consistent with this assertion, we noted in field notes how in Spring data review meetings teachers did not expect improvements in all aspects of students' performance (viewing education as a longer-term process). But they were very disappointed if gains were not observed in areas where they had chosen to invest concerted effort (as reflected in Table 5).

What stood out as important in our quantitative analysis was that instruction that combined the four qualities we observed (sustained, integrated, and explicit instruction focused on supporting student independence) was most highly related to gains on the LTRQ, particularly when teachers focused instruction on achieving the following goals (see Table 7): (1) making inferences, which was most highly related to gains for students across LTRQ dimensions, including motivation, emotion, cognition, and metacognition; (2) reasoned judgments; (3) main ideas; (4) note-making. In contrast, a sustained focus on details was associated with greater stress and worry and greater use of motivation and emotion control strategies. A focus on visualizing was negatively related to strategies for working with text. A focus on text features was negatively related to attributions for success to controllable factors (effort, strategies) and to positive emotions. Overall, findings combined to suggest that gains were greatest when teachers invested sustained effort in fostering students' engagement in higher-level reading, learning, and thinking processes.
We also used regression analyses to relate particular goals and implementation qualities (i.e., sustained; integrated into curricula; explicit; supporting student independence) to gains on the LTRQ. When taken together, implementation quality variables predicted up to $70 \%$ of the variance on LTRQ gains. Note again that the strongest relationships between practice qualities and LTRQ gains across components (including the most active learning ones) happened when teachers selected making inferences as a goal and, to a much lesser extent, main ideas. Based on these data, we concluded that SRL-supportive practices focused on active learning goals achieved the greatest gains in students' perceptions about LTR activities and their engagement within them. Also notable was that gains were most evident when teachers' practices moved towards promoting independence. For example, gains were greater when teachers moved beyond just scaffolding or guiding students' learning to supporting students' reflective, deliberate decision-making (e.g., about which strategies might help them in achieving a given goal).

5.3.3. Relating Qualities of Instruction to PBA Gains for Students. We did not find direct positive relationships between practice qualities and gains for students on the PBA. However, as described earlier, we did find that practice qualities strongly predicted gains on the LTRQ, suggesting that teachers' instruction could be related to how students thought about their engagement in LTR activities. Further, findings suggested that pre-post gains on the LTRQ were strongly associated with gains on the PBA (see Table 8). This latter finding suggests that students' perceptions about their engagement in LTR may have mediated shifts in actual performance. Further research is needed to test this possibility.

\section{Discussion and Conclusions}

This research investigated relationships between teachers' engagement in cycles of self- and co-regulated inquiry, practice change, and the promotion of students' self-regulated engagement in what is a ubiquitous requirement in educational settings, namely, LTR. Over time, our findings have converged with other research to suggest that secondary students experience significant challenges with LTR in subject-area classrooms [46, 83, 87]. More encouragingly, our research also suggests that subject-area teachers can be inspired and supported to modify instructional practices to support adolescent literacy within an inquiry-based professional development framework (see also [3, 4]).

One way in which the research reported here extends previous research is by advancing understanding about practice qualities with promise to advance students' engagement in self-regulated LTR. In particular, findings reported here suggest that practices that push students to deliberately learn from classroom activities (i.e., by fostering independence) are most highly associated with gains in self-regulation (see also $[44,66])$. As we reflected on these findings in relation to prior research on challenges to students' selfregulated LTR, we started to wonder whether it might be productive to extend the SRP/SRL distinction we have found 


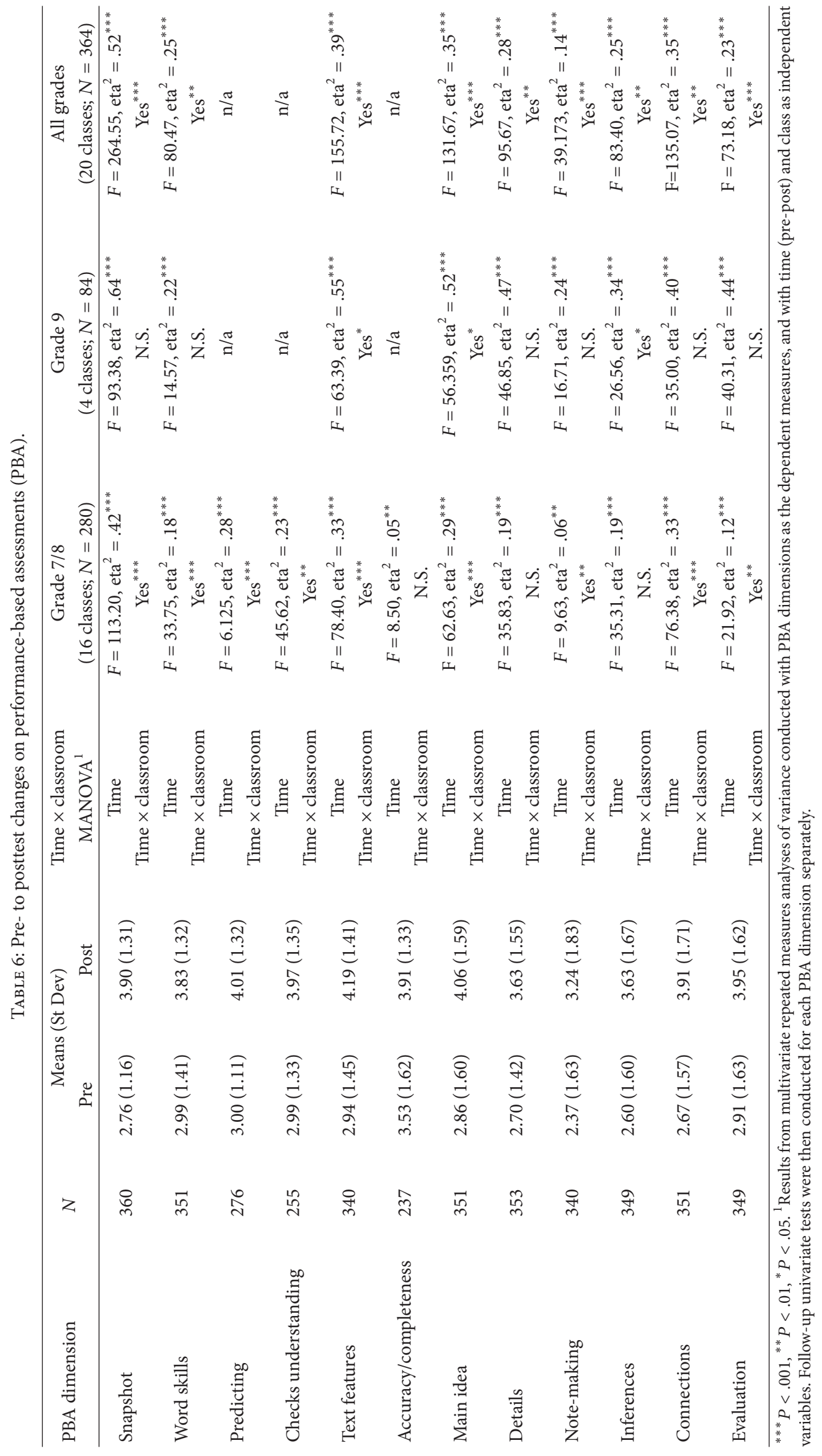


TABLE 7: Correlations between implementation quality and LTRQ gains for goals selected by teachers.

\begin{tabular}{|c|c|c|c|c|c|c|c|c|}
\hline \multirow{2}{*}{ LTRQ dimensions } & \multicolumn{8}{|c|}{ Goals selected by teachers } \\
\hline & Main ideas & Details & Note-making & Connections & Inferencing & Visualizing & Text features & Reasoned judgments \\
\hline $\begin{array}{l}\text { Perceptions of } \\
\text { competence and } \\
\text { control }\end{array}$ & .30 & -.26 & .11 & .01 & .29 & -.06 & -.14 & -.00 \\
\hline $\begin{array}{l}\text { Controllable } \\
\text { attributions }\end{array}$ & .32 & .06 & $.43(.06)$ & -.16 & $.46^{*}$ & .09 & $-.59^{* *}$ & .10 \\
\hline External attributions & -.21 & .12 & -.28 & .21 & -.06 & .14 & -.03 & .18 \\
\hline Task value & $.46^{*}$ & .14 & .28 & -.02 & .32 & .12 & -.20 & -.06 \\
\hline $\begin{array}{l}\text { Positive personal } \\
\text { goals }\end{array}$ & $.50^{*}$ & -.18 & .27 & .22 & $.46^{*}$ & .16 & .14 & .21 \\
\hline Positive emotions & .24 & .06 & .13 & .09 & $.52^{*}$ & .13 & $-.55^{*}$ & $.41(.07)$ \\
\hline Stress and worry & -.26 & $.43(.06)$ & -.18 & .06 & -.13 & -.14 & -.03 & .07 \\
\hline $\begin{array}{l}\text { Positive task } \\
\text { interpretation }\end{array}$ & .41 & .08 & $.41(.07)$ & -.16 & .21 & -.15 & .14 & -.14 \\
\hline Positive criteria & .23 & -.23 & .15 & -.30 & .36 & -.40 & -.28 & -.04 \\
\hline Planning & .26 & .07 & -.03 & .22 & $.51^{*}$ & .10 & -.30 & $.45^{*}$ \\
\hline $\begin{array}{l}\text { Monitoring: } \\
\text { learning }\end{array}$ & $.46^{*}$ & -.00 & .04 & .06 & $.49^{*}$ & -.12 & -.19 & .26 \\
\hline $\begin{array}{l}\text { Monitoring: work } \\
\text { progress/methods }\end{array}$ & .33 & .03 & -.10 & -.02 & .30 & -.23 & -.16 & .08 \\
\hline $\begin{array}{l}\text { Adjusting: working } \\
\text { with text and } \\
\text { rereading }\end{array}$ & .22 & .12 & .07 & -.24 & .24 & -.17 & -.26 & .08 \\
\hline $\begin{array}{l}\text { Adjusting: linking } \\
\text { information }\end{array}$ & .37 & -.21 & .12 & .14 & $.57^{* *}$ & .06 & -.23 & $.40(.08)$ \\
\hline $\begin{array}{l}\text { Adjusting: work } \\
\text { management }\end{array}$ & .34 & -.08 & .18 & .01 & $.57^{* *}$ & .01 & -.35 & $.42(.06)$ \\
\hline $\begin{array}{l}\text { Emotion/motivation } \\
\text { control }\end{array}$ & .38 & $.41(.07)$ & .18 & .08 & .28 & -.03 & -.05 & .07 \\
\hline Self-evaluating & $.47^{*}$ & -.03 & .14 & -.09 & $.46^{*}$ & -.16 & -.11 & .20 \\
\hline $\begin{array}{l}\text { Working with } \\
\text { information }\end{array}$ & .33 & .06 & .04 & .09 & $.59^{* *}$ & -.07 & -.27 & $.47^{*}$ \\
\hline Working with text & .22 & -.36 & .07 & -.26 & .28 & $-.53^{*}$ & -.04 & .10 \\
\hline Focus on memory & .33 & -.26 & .08 & -.22 & .33 & -.08 & -.25 & -.01 \\
\hline Help seeking & .23 & .11 & -.31 & .27 & .08 & .02 & .27 & -.02 \\
\hline Disengaged & $-.50^{*}$ & -.05 & -.31 & .13 & -.20 & .10 & .04 & .26 \\
\hline External focus & .04 & -.16 & -.18 & .36 & $.40(.08)$ & .18 & -.27 & $.48^{*}$ \\
\hline
\end{tabular}

${ }^{* * *} P<.001,{ }^{* *} P<.01,{ }^{*} P<.05$; parens are used to flag effects that suggest a trend, but do not achieve a .05 level of significance (e.g., $\left.P<.07\right)$.

useful in understanding teachers' professional development to conceptualizing students' self-regulated engagement in classrooms.

For example, in classrooms, students are also engaged in a particular kind of socially constructed practice, namely, academic work as constituted in schools [88, 89]. Teachers typically engage students in these forms of academic work in hope that they will deliberately learn in/through those experiences. But students cannot be expected to just "know" how to engage in academic practices. Instead, teachers' roles in part need to be demystifying the demands of academic work as constituted in particular contexts (i.e., communities, disciplines, and classrooms). Adopting this perspective affords a richer, sociocultural analysis of where and why SRP/SRL might break down in schools, as might be the case if students fail to appreciate discipline-specific norms for constructing and communicating knowledge (e.g., in science and in history). Similarly, students assigned activities that primarily involve learning facts from textbooks may come to define science or history as fields of practice that involve memorizing facts established by experts [77]. Moves towards more inquiry-oriented or problem-based approaches can be conceptualized as attempts to engage students in more "authentic" forms of practice (e.g., designing an experiment like a scientist) as a foundation on which they can anchor both content and process learning $[90,91]$. 


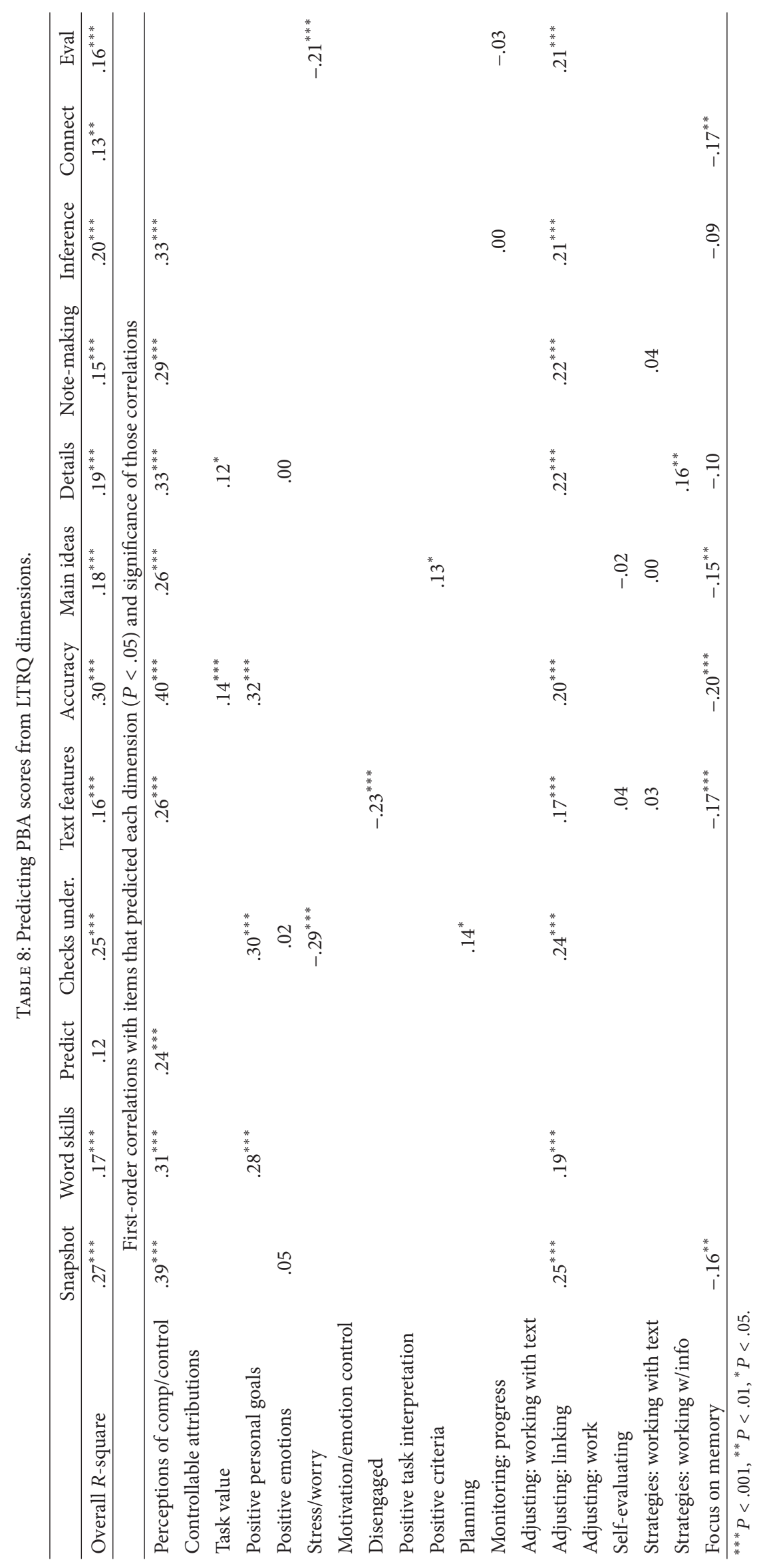


Further, drawing on an SRP/SRL distinction, it could be argued that if students are to learn actively, they need to deliberately shift from "getting through teacher-assigned tasks," or just learning incidentally through that experience, towards deliberately learning about, during, or from classroom activities. For example, many students seem to derive strategies for achieving good grades by working mechanically through assignments to fulfill expectations (e.g., to answer end-ofthe-chapter questions), without self-regulating their learning from or through that activity (e.g., by connecting what they know with prior knowledge, forming opinions they can defend, or testing their understanding). In classrooms, SRL may be enabled when students are supported to deliberately plan for and monitor how they are constructing knowledge or skill while engaged in activities (i.e., practices) designed to promote active learning [66]. Connecting SRP and SRL for students may require constructing academic work in ways that encourage students to deliberately manage their learning in/through meaningful practice (e.g., deliberately learning from and through LTR activities). Our findings that gains in LTRQ scores were associated with teachers' push for independence are consistent with this suggestion.

Considering our contributions more broadly, what we have achieved in this research has been to take up the challenge to study SR as a complex, multicomponential, dynamic, and layered process as it unfolds for students and teachers within schools and classrooms. Here, we would highlight the heuristic value of the theoretical framework we have been drawing on to guide our research into self- and coregulation as situated in practice (see Figure 1). Theoretically speaking, our model of self- and co-regulation as situated in activity has afforded drawing useful distinctions, for example, between SRP and SRL, and uncovering important dependencies, for example, in how forms of self- and co-regulation are supported and delimited in the context of social practice. From a practice perspective, we have found that teachers value the model and associated assessment tools for how they draw attention to highly important instructional goals and inform directions for practice. We have also contributed by advancing knowledge about how teachers can be supported to construct practices supportive of self-regulated LTR in authentic classroom settings.

Another main contribution offered by this research program overall has been in defining innovative methodological strategies for the study of self- and co-regulation. There are certainly many exciting methodological designs and tools being developed with great potential to advance understanding about self-regulation as a complex, multicomponential, dynamic, and situated event (see [92]). A limitation of this research study is that we did not take full advantage of some of these other approaches as part of our methodological tool kit (e.g., more online microanalyses of students' selfregulation while actually engaged in LTR). But what we have contributed are ways of thinking about and studying selfand co-regulation that preserve meaning in context. For example, our self-report and performance-based tools assess important components implicated in self-regulation (i.e., motivation, emotion, cognition, and metacognition) in ways that reference the demands of activities and environments.
Our case study methodology can be productively applied to investigate interconnections between teachers' and students' self- and co-regulated learning and practice. In so doing, we have highlighted how investigating self- and co-regulation requires attending to how learning is constituted within and by the kinds of social practices through which individuals work and learn.

While results from this line of research have been promising, it is important to acknowledge important limitations to this work that should be taken up in future research. First, our sample here was limited to just three schools located within one school district in Western Canada. Further, when linking practice shifts to learning outcomes, we focused just on practices enacted by 12 teachers working across 20 humanities classrooms with just 364 students. Clearly, additional research is needed to consider how findings generated in this context might be meaningful in other settings. Further, while we employed a variety of methodological lenses to study how goals and practices taken up in classrooms were related to students' learning in those settings, either broadening or narrowing the sampling strategy could extend understanding about how practices are related to students' learning. On one hand, including a larger, more diverse sample in the research frame might enable a more multilayered assessment of how student learning gains can be accounted for by variables at the student, classroom, school, and even district levels. On the other hand, more fine-grained microanalyses at the individual level could afford tracing shifts in students' learning processes and achievement with more specificity.

An interesting puzzle presented by our findings was that the qualities of practices we coded, while strongly related to gains in LTRQ scores for students, were not directly associated with gains on the PBA. One potential explanation is that the practice qualities teachers "added" in this research were closely focused on improving self-regulation (e.g., students' deliberate orchestration of learning processes). The kinds of changes these subject-area teachers made in their practices did tend to integrate attention to learning processes with more content-focused instruction. It is perhaps not surprising, then, that the most notable direct effects of teachers' practice changes were on students' thinking about LTR activities and their engagement within them. It is possible that the gains observed here in students' literacy performance were mediated by gains in self-regulation. That said, it is also possible that we missed cataloguing qualities of practices in our coding scheme that were more directly related to PBA gains. Thus, further research is certainly needed into how practice qualities are directly and/or indirectly related to gains in self-regulation and/or achievement.

In conclusion, in the research reported on here, we traced how teachers' practice revisions can and do emerge from their reflective engagement in cycles of self- and co-regulated inquiry (see [2-4]). Extending from previous reports focused on students' self-regulated LTR or on teachers' professional development, this paper contributes by connecting the dots between teacher learning, practice development, and outcomes for learners. Based on findings reported here, we conclude that when student and teacher self- and co-regulation are considered and nurtured in relation to one another, 
desired links can be achieved between practice changes and positive outcomes for students.

\section{Acknowledgments}

The authors would like to thank Ryan Brydges for his very insightful comments on an earlier draft of this paper. Portions of this paper were presented at the annual meeting of the International Reading Association, Atlanta, GA, USA. This research was supported by a Standard Research Grant to the first author from the Social Sciences and Humanities Research Council of Canada.

\section{References}

[1] D. L. Butler, S. C. Cartier, L. Schnellert, F. Gagnon, and M. Giammarino, "Secondary students' self-regulated engagement in reading: researching self-regulation as situated in context," Psychological Test and Assessment Modeling, vol. 53, no. 1, pp. 73-105, 2011.

[2] D. L. Butler, L. Schnellert, and S. C. Cartier, "Educational change and layers of self-regulation: teachers working strategically to improve practice so as to foster student self-regulation," in Proceedings of the Annual Conference of the American Educational Research Association, New York, NY, USA, 2008.

[3] L. M. Schnellert, D. L. Butler, and S. K. Higginson, "Coconstructors of data, co-constructors of meaning: teacher professional development in an age of accountability," Teaching and Teacher Education, vol. 24, no. 3, pp. 725-750, 2008.

[4] D. L. Butler and L. Schnellert, "Collaborative inquiry in teacher professional development," Teaching and Teacher Education, vol. 28, pp. 1206-1220, 2012, http://dx.doi.org/ 10.1016/j.tate.2012.07.009.

[5] H. Borko, "Professional development and teacher learning: mapping the terrain," Educational Researcher, vol. 33, no. 8, pp. 3-15, 2004.

[6] M. Cochran-Smith and S. L. Lytle, "Practitioner inquiry, knowledge, and university culture," in International Handbook of Self-Study and Teacher Education Practices, J. Loughran, M. L. Hamilton, V. LaBoskey, and T. Russell, Eds., pp. 601-649, Kluwer Academic, London, UK, 2004.

[7] B. J. Fishman, R. W. Marx, S. Best, and R. T. Tal, "Linking teacher and student learning to improve professional development in systemic reform," Teaching and Teacher Education, vol. 19, no. 6, pp. 643-658, 2003.

[8] K. M. Zeichner and S. E. Noffke, "Practitioner research," in Handbook of Research on Teaching, V. Richardson, Ed., pp. 298-330, 4th edition, 2001.

[9] G. G. Duffy, "Teachers who improve reading achievement," in Improving Reading Achievement through Professional Development, D. S. Stickland and M. L. Kamala, Eds., pp. 3-22, Christopher-Gordon Publishers, Norwood, Mass, USA, 2004.

[10] B. Joyce and B. Showers, Achievement through Staff Development, Association for the Supervision of Curriculum Development, Alexandria, Va, USA, 2002.

[11] H. Timperley and A. Alton-Lee, "Reframing teacher professional learning: an alternative policy approach to strengthening valued outcomes for diverse learners," Review of Research in Education, vol. 32, no. 1, pp. 328-369, 2008.

[12] D. L. Butler, H. J. Novak Lauscher, S. Jarvis-Selinger, and B. Beckingham, "Collaboration and self-regulation in teachers' professional development," Teaching and Teacher Education, vol. 20, no. 5, pp. 435-455, 2004.

[13] D. L. Ball and D. K. Cohen, "Developing practice, developing practitioners: toward a practice-based theory of professional education," in Teaching as the Learning Profession: Handbook of Policy and Practice, L. Darling-Hammond and G. Sykes, Eds., pp. 3-32, Jossey-Bass Publishers, San Francisco, Calif, USA, 1999.

[14] A. S. Palincsar, "Response: a community of practice," Teacher Education and Special Education, vol. 22, no. 4, pp. 272-274, 1999.

[15] L. Schnellert, Collaborative inquiry: teacher professional development as situated, responsive co-construction of practice and learning [Doctoral dissertation], 2011, https://circle.ubc.ca/ handle/2429/38245.

[16] T. P. Carpenter, E. Fennema, and M. L. Franke, "Cognitively guided instruction: a knowledge base for reform in primary mathematics instruction," The Elementary School Journal, vol. 97, no. 1, pp. 3-20, 1996.

[17] S. K. Henry, J. A. Scott, J. Wells et al., "Linking university and teacher communities: a "Think Tank" model of professional development," Teacher Education and Special Education, vol. 22, no. 4, pp. 251-268, 1999.

[18] J. J. Loughran, "Effective reflective practice in search of meaning in learning about teaching," Journal of Teacher Education, vol. 53, no. 1, pp. 33-43, 2002.

[19] C. Luna, M. J. Botelho, D. Fontaine, K. French, K. Iverson, and N. Matos, "Making the road by walking and talking: critical literacy and/as professional development in a teacher inquiry group," Teacher Education Quarterly, vol. 32, no. 1, pp. 67-80, 2004.

[20] E. Morrell, "Legitimate peripheral participation as professional development: lessons from a summer research seminar," Teacher Education Quarterly, vol. 32, no. 1, pp. 89-99, 2004.

[21] J. M. Robertson, "The three R's of action-research methodology: reciprocity, reflexivity and reflection-on-reality," Educational Action Research, vol. 8, no. 2, pp. 307-326, 2000.

[22] D. L. Butler, L. Schnellert, and S. Higginson, "Fostering agency and co-regulation: teachers using formative assessment to calibrate practice in an age of accountability," in Proceedings of the Annual Conference of the American Educational Research Association, Chicago, Ill, USA, 2007, http://ecps.educ .ubc.ca/sped/faculty/deborah-l-butler-phd.

[23] D. L. Butler and P. H. Winne, "Feedback and self-regulated learning: a theoretical synthesis," Review of Educational Research, vol. 65, pp. 245-281, 1995.

[24] L. Corno, "The best laid plans: modern conceptions of volition and educational research," Educational Researcher, vol. 22, no. 2, pp. 14-22, 1993.

[25] L. Corno, "Student volition and education: outcomes, influences, and practices," in Self-Regulation of Learning and Performance: Issues and Educational Applications, D. H. Schunk and B. J. Zimmerman, Eds., pp. 229-251, Lawrence Erlbaum Associates, Hillsdale, NJ, USA, 1994.

[26] S. Paris, J. Byrnes, and A. Paris, "Constructing theories, identities and actions of self-regulated learners," in Self-Regulated Learning and Academic Achievement: Theoretical Perspectives, B. Zimmerman and D. Schunk, Eds., pp. 253-288, Lawrence Erlbaum Associates, Mahwah, NJ, USA, 2001.

[27] P. R. Pintrich, "The role of goal orientation in self-regulated learning," in Handbook of Self-Regulation, M. Boekaerts, P. R. 
Pintrich, and M. Zeidner, Eds., pp. 451-502, Academic Press, San Diego, Calif, USA, 2000.

[28] M. Wang, G. Haertel, and H. Walberg, "Toward a knowledge base for school learning," Review of Educational Research, vol. 63, pp. 249-294, 1993.

[29] P. H. Winne and A. Hadwin, "Studying as self-regulated learning," in Metacognition in Educational Theory and Practice, D. Hacker, J. Dunlosky, and A. Graesser, Eds., pp. 279-306, Lawrence Erlbaum Associates, Hillsdale, NJ, USA, 1998.

[30] B. J. Zimmerman, "Attaining self-regulation: a social cognitive perspective," in Handbook of Self-Regulation, M. Boekaerts, P. R. Pintrich, and M. Zeidner, Eds., pp. 13-39, Academic Press, New York, NY, USA, 2000.

[31] T. Guskey, Evaluating Professional Development, Corwin Press, Thousand Oaks, Calif, USA, 2000.

[32] D. Hopkins, "Schooling for tomorrow: innovations and networks,” OECD/CERI, Lisbon, Portugal, 2000.

[33] C. McLaughlin, K. Black-Hawkins, and D. McIntyre, Researching Teachers, Researching Schools, Researching Networks: A Review of the Literature, University of Cambridge, Cambridge, UK, 2004.

[34] B. J. Zimmerman, "Investigating self-regulation and motivation: historical background, methodological developments, and future prospects," American Educational Research Journal, vol. 45, no. 1, pp. 166-183, 2008.

[35] D. L. Butler, "Structuring instruction to promote self-regulated learning by adolescents and adults with learning disabilities," Exceptionality, vol. 11, no. 1, pp. 39-60, 2003.

[36] B. J. Zimmerman and D. H. Schunk, "Reflections on theories of self-regulated learning and academic achievement," in SelfRegulated Learning and Academic Achievement: Theoretical Perspectives, B. J. Zimmerman and D. H. Schunk, Eds., pp. 289-307, Lawrence Erlbaum Associates, Mahwah, NJ, USA, 2nd edition, 2001.

[37] B. J. Zimmerman, "Becoming a self-regulated learner: an overview," Theory into Practice, vol. 41, no. 2, pp. 64-70, 2002.

[38] D. L. Butler, "Promoting strategic learning by postsecondary students with learning disabilities," Journal of Learning Disabilities, vol. 28, no. 3, pp. 170-190, 1995.

[39] D. K. Meyer and J. C. Turner, "Using instructional discourse analysis to study the scaffolding of student self-regulation," Educational Psychologist, vol. 37, no. 1, pp. 17-25, 2002.

[40] S. Volet, M. Summers, and J. Thurman, "High-level coregulation in collaborative learning: how does it emerge and how is it sustained?" Learning and Instruction, vol. 19, no. 2, pp. 128-143, 2009.

[41] A. S. Palincsar and A. L. Brown, "Teaching and practicing thinking skills to promote comprehension in the context of group problem solving," Remedial and Special Education, vol. 9, no. 1, pp. 53-59, 1988.

[42] M. Pressley, P. B. El-Dinary, I. W. Gaskins et al., "Beyond direct explanation: transactional instruction of reading comprehension strategies," The Elementary School Journal, vol. 92, pp. 513-555, 1992.

[43] D. L. Butler, "The strategic content learning approach to promoting self-regulated learning: a report of three studies," Journal of Educational Psychology, vol. 90, no. 4, pp. 682-697, 1998.

[44] S. C. Cartier, D. L. Butler, and N. Bouchard, "Teachers working together to foster self-regulated learning through reading by students in an elementary school located in a disadvantaged area," Psychological Test and Assessment Modeling, vol. 52, no. 4, pp. 382-418, 2010.

[45] D. L. Butler and L. Schnellert, "Bridging the research-topractice divide: improving outcomes for students," Education Canada, vol. 48, no. 5, pp. 36-40, 2008.

[46] M. L. Barton, "Addressing the literacy crisis: teaching reading in the content areas," NASSP Bulletin, vol. 81, no. 587, pp. 22-30, 1997.

[47] S. Cartier and R. Viau, "Analyse des Écrits Scientifiques et Professionnels Traitant de l'Apprentissage par la Lecture d'Élèves du Secondaire qui ont des Difficultés d'Apprentissage," Tech. Rep. 1, University of Montreal, Montreal, Canada, 2001.

[48] J. Ciborowski, "Using textbooks with students who cannot read them," Remedial and Special Education, vol. 16, no. 2, pp. 90-101, 1995.

[49] E. S. Ellis and B. K. Lenz, "Techniques for meditating contentarea learning: issues and research," Focus on Exceptional Children, vol. 22, no. 9, pp. 1-16, 1990.

[50] V. Lindberg, "Learning practices in vocational education," Scandinavian Journal of Educational Research, vol. 47, no. 2, pp. 157-179, 2003.

[51] R. T. Vacca, "Let's not marginalize adolescent literacy," Journal of Adolescent and Adult Literacy, vol. 41, no. 8, pp. 604-609, 1998.

[52] J. Burke, Illuminating Texts: How to Teach Students to Read the World, Butterworth Heinemann, Portsmouth, NH, USA, 2001.

[53] S. C. Cartier, "Cadre conceptuel d'analyse de la situation d'apprentissage par la lecture et des difficultés éprouvées par les étudiants," Res Academica, vol. 18, no. 1-2, pp. 91-104, 2000.

[54] J. Rycik and J. Irwin, Reading in the Middle Grades, Pearson Education, Toronto, Canada, 2005.

[55] E. G. Stetson and R. P. Williams, "Learning from Humanities textbooks: why some students succeed and others fail," Journal of Reading, vol. 36, no. 1, pp. 22-30, 1992.

[56] R. T. Vacca, J. L. Vacca, and D. Begoray, Content Area Reading: Literacy and Learning Across the Curriculum, Allyn and Bacon, Boston, Mass, USA, 2005.

[57] D. E. Alvermann, "Effective literacy instruction for adolescents," in Proceedings of the National Reading Conference, Chicago, Ill, USA, 2001.

[58] M. Pressley, "Metacognition and self-regulated comprehension," in What Research Has to Say about Reading Instruction, A. Farstrup and J. Samuels, Eds., pp. 291-309, International Reading Association, Newark, Del, USA, 2002.

[59] J. A. Dole, G. G. Duffy, L. R. Roehler, and P. D. Pearson, "Moving from the old to the new: research on reading comprehension instruction," Review of Educational Research, vol. 61, pp. 239-264, 1991.

[60] D. L. Butler and S. C. Cartier, "Learning in varying activities: an explanatory framework and a new evaluation tool founded on a model of self-regulated learning," in Proceedings of the Annual Conference of the Canadian Society for the Study of Education, Winnipeg, Canada, 2004, http://ecps.educ .ubc.ca/sped/faculty/deborah-l-butler-phd.

[61] S. C. Cartier and D. L. Butler, "Apprendre en lisant et en expérimentant: description des recherches présentement réalisées au Québec et en Colombie Britannique," in Proceedings of the Annual Conference of the Canadian Society for the Study of Education, Winnipeg, Canada, http://ecps.educ .ubc.ca/sped/faculty/deborah-l-butler-phd.

[62] S. C. Cartier, "Stratégies d’apprentissage par la lecture délèves en difficulté d’apprentissage qui fréquentent une classe de 
cheminement particulier de formation en première secondaire," Revue des sciences de léducation, vol. 32, no. 2, pp. 439-460, 2006.

[63] A. Bandura, "Exercise of human agency through collective efficacy," Current Directions in Psychological Science, vol. 9, no. 3, pp. 75-78, 2000.

[64] S. C. Cartier, R. Chouinard, and D. L. Butler, "The impact of evaluative approaches on high school students' learning through reading engagement," in Proceedings of the Annual Conference of the American Educational Research Association, New York, NY, USA, 2008.

[65] N. E. Perry, "Young children's self-regulated learning and contexts that support it," Journal of Educational Psychology, vol. 90, no. 4, pp. 715-729, 1998.

[66] N. Perry, L. Phillips, and J. Dowler, "Examining features of tasks and their potential to promote self-regulated learning," Teachers College Record, vol. 106, no. 9, pp. 1854-1878, 2004.

[67] S. C. Cartier, Apprendre en Lisant au Primaire et au Secondaire, Éditions CÉC, Anjou, France, 2007.

[68] D. L. Butler, "Investigating self-regulated learning using indepth case studies," in Handbook of Self-Regulation of Learning and Performance, B. J. Zimmerman and D. H. Schunk, Eds., pp. 346-360, Routledge, New York, NY, USA, 2011.

[69] S. B. Merriam, Qualitative Research and Case Study Applications in Education, Jossey-Bass, San Francisco, Calif, USA, 1998.

[70] R. K. Yin, Case Study Research: Design and Methods, Sage, Thousand Oaks, Calif, USA, 3rd edition, 2003.

[71] D. L. Butler, L. Schnellert, and K. MacNeill, "Teachers working collaboratively to support adolescent literacy: a case study of a multi-level community of inquiry," in Proceedings of the Annual Conference of the American Educational Research Association, Vancouver, Canada, 2012.

[72] J. Scott, How instruction supportive of self-regulated learning might foster self-efficacy for students with and without learning disabilities during literacy tasks [M.S. thesis], 2011, https://circle.ubc.ca/handle/2429/35970.

[73] W. S. Nielsen, Group work and metacognition: an exploratory case [Doctoral dissertation], 2008, https://circle.ubc.ca/handle/ 2429/7559.

[74] M. Giammarino, Mathematical Flexibility [M.S. thesis], 2010, https://circle.ubc.ca/handle/2429/28459.

[75] O. Lawanto, D. L. Butler, S. C. Cartier, H. B. Santoso, K. N. Lawanto, and D. Clark, "An exploratory study of self-regulated learningstrategies in a design project by students in grades 9-12," Design and Technology Education: An International Journal, vol.18, no. 1. In press.

[76] A. Tang, ESL students' academic help seeking and help avoidance: an exploratory multiple-case study in secondary classrooms [M.S. thesis], 2009, https://circle.ubc.ca/handle/2429/17431.

[77] D. L. Butler, C. Pollock, K. Nomme, and J. Nakonechny, "Promoting authentic inquiry in the sciences: challenges faced in redefining first-year university students' scientific epistemology," in Inquiry in Education: Overcoming Barriers To Successful Implementation, B. M. Shore, M. W. Aulls, and M. A. B. Delcourt, Eds., pp. 301-324, Lawrence Erlbaum Associates, New York, NY, USA, Taylor \& Francis, Boca Raton, Fla, USA, 2008.

[78] F. Brownlie, C. Feniak, and L. Schnellert, Student Diversity, Pembroke Publishers, Markham, Canada, 2nd edition, 2006.

[79] D. L. Butler, S. C. Cartier, L. Schnellert, and F. Gagnon, "Secondary students' self-regulated engagement in "learning through reading": findings from an integrative research project," in Proceedings of the Annual Conference of the Canadian Society for the Study of Education, Toronto, Canada, 2006, http://ecps.educ.ubc.ca/sped/faculty/deborah-l-butler-phd.

[80] Y. S. Lincoln and E. G. Guba, Naturalistic Inquiry, Sage, Newbury Park, Calif, USA, 1985.

[81] M. B. Miles and A. M. Huberman, Qualitative Data Analysis: An Expanded Sourcebook, Sage, Thousand Oaks, Calif, USA, 2n edition, 1994.

[82] M. H. Agar, The Professional Stranger: An Informal Introduction to Ethnography, Academic Press, Toronto, Canda, 2nd edition, 1996.

[83] J. Lewis, "Academic literacy: principles and learning opportunities for adolescent readers," in Adolescent Literacy Instruction, J. Lewis and G. Moorman, Eds., pp. 143-166, International Reading Association, Newark, Del, USA, 2007.

[84] M. L. Barton and D. Jordan, Reading in Science, Mid-Continent Research for Education and Learning (McREL), Aurora, Colo, USA, 2001.

[85] S. Cartier and M. Théorêt, "Lire Pour Apprendre: Une Compétence à Maîtriser au Secondaire," Tech. Rep., The Québec Ministry of Education: Programme de soutien à l'école montréalaise, 2001.

[86] M. L. Kamil, Adolescents and Literacy: Reading For the 21st Century, Alliance for Excellent Education, Washington, DC, USA, 2003.

[87] E. B. Moje, "Developing socially just subject-matter instruction: a review of the literature on disciplinary literacy teaching," Review of Research in Education, vol. 31, pp. 1-44, 2007.

[88] P. H. Winne and R. W. Marx, "Students' and teachers'views of thinking processes for classroom learning," Elementary School Journal, vol. 82, pp. 493-518, 1982.

[89] A. H. Schoenfeld, "Problem solving in context(s)," in The Teaching and Assessing of Mathematical Problem Solving, R. I. Charles and E. A. Silver, Eds., vol. 3, pp. 82-92, Lawrence Erlbaum Associates, Hillsdale, NJ, USA, 1988.

[90] R. Brydges and D. L. Butler, "A reflective analysis of medical education research on self-regulation in learning and practice," Medical Education, vol. 46, pp. 71-79, 2012.

[91] C. A. Chinn and B. A. Malhotra, "Epistemologically authentic inquiry in schools: a theoretical framework for evaluating inquiry tasks," Science Education, vol. 86, no. 2, pp. 175-218, 2002.

[92] B. J. Zimmerman and D. H. Schunk, Eds., Handbook of SelfRegulation of Learning and Performance, Routledge, New York, NY, USA, 2011.

[93] N. Duke and P. D. Pearson, "Effective practices for developing reading comprehension," in What Research Has to Say About Reading, A. Farstrup and J. Samuels, Eds., pp. 205-242, International Reading Association, Newark, Del, USA, 2002.

[94] D. A. McAndrew, Literacy Leadership: Six Strategies For Peoplework, International Reading Association, Newark, Del, USA, 2005. 

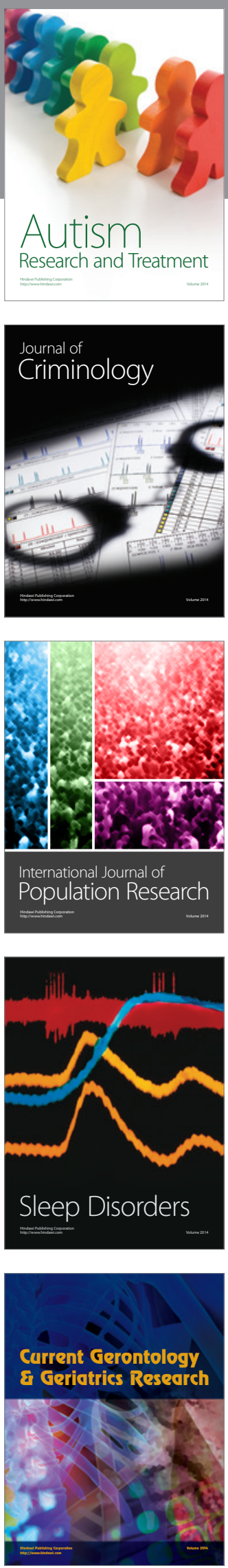
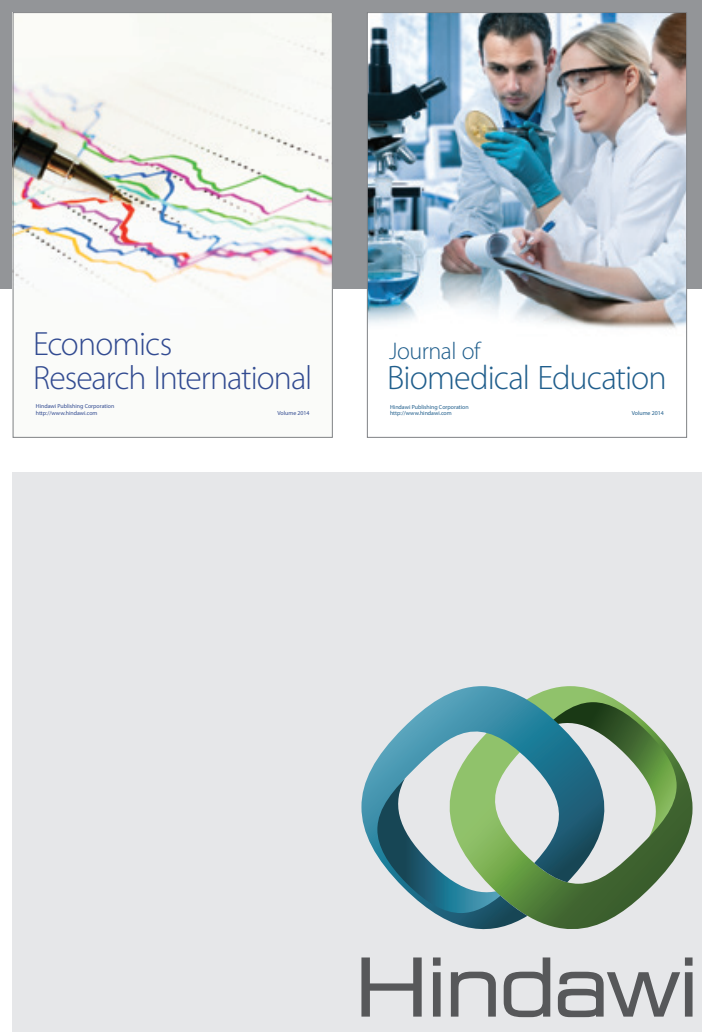

Submit your manuscripts at

http://www.hindawi.com
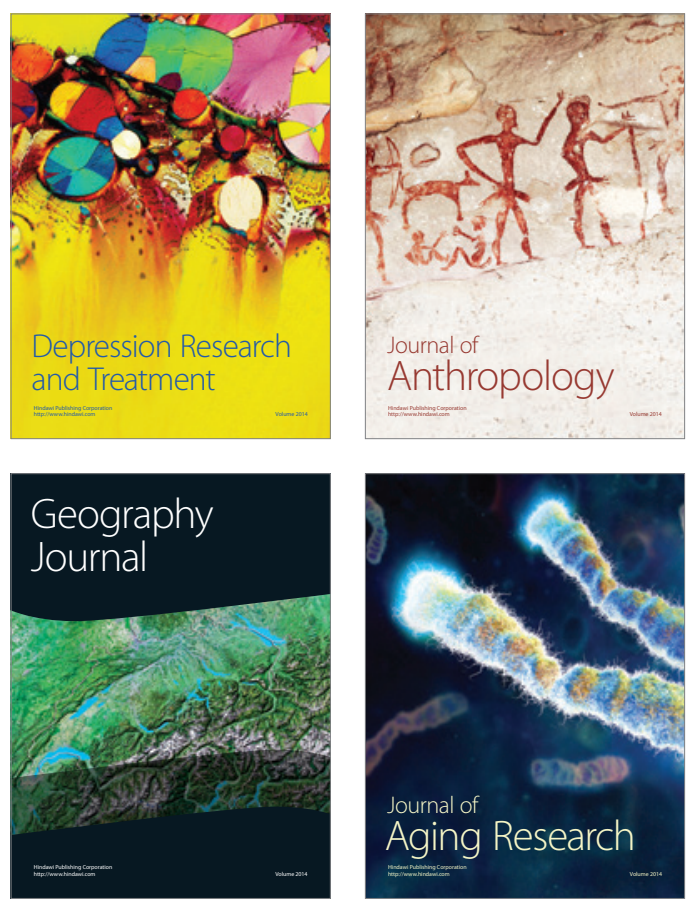
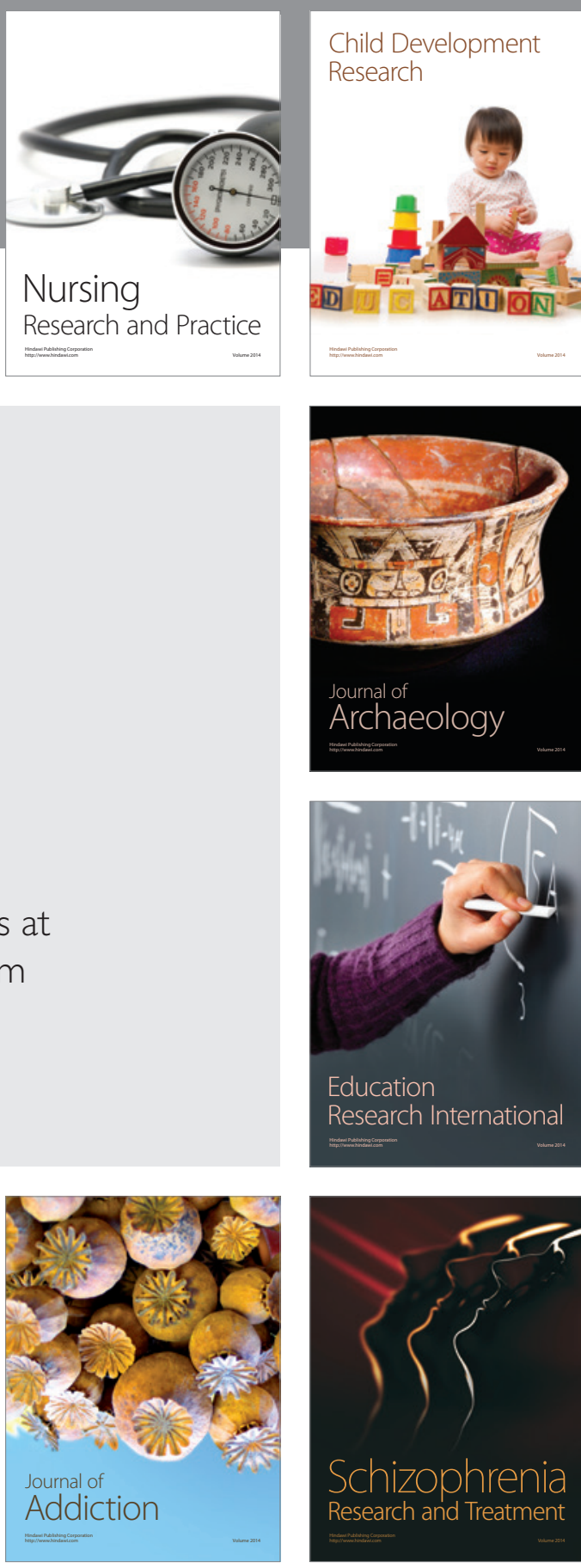

(D)
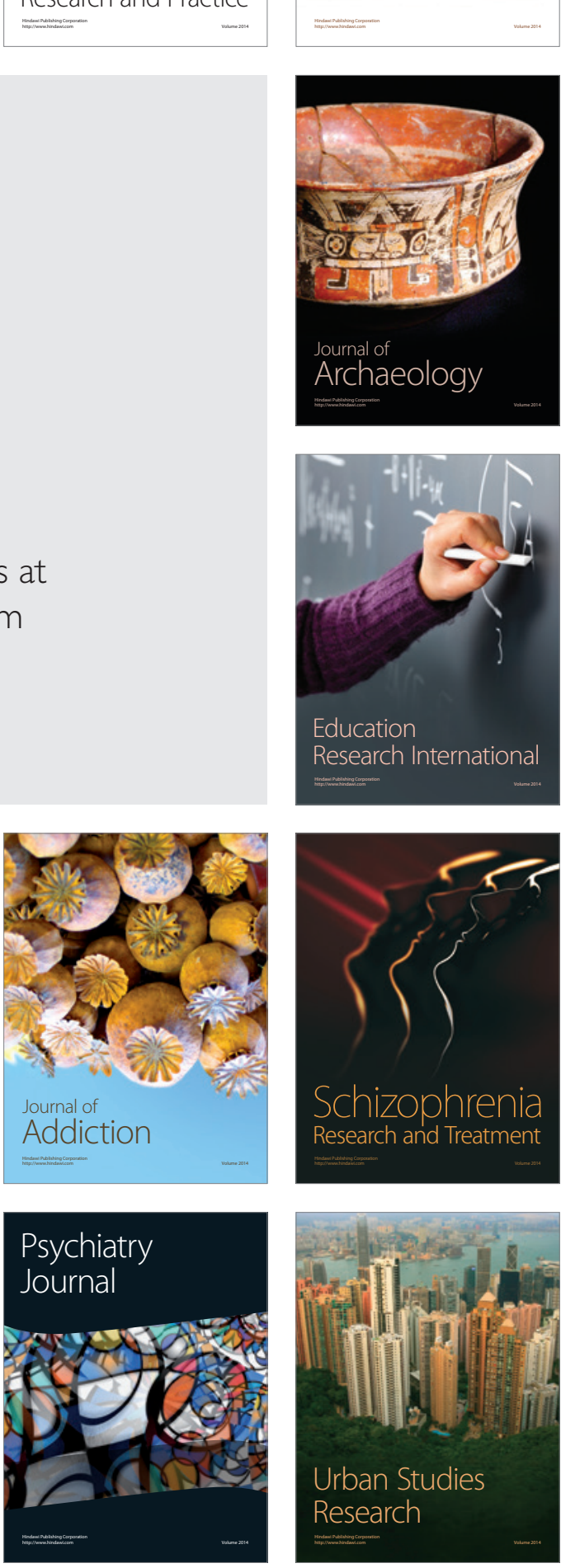